\title{
MATERIALES CALCOLITICOS PROCEDENTES DE "LA LONGUERA" (EL VISO, CÓRDOBA)
}

\author{
Juan F. MURILLO REDONDO (*) \\ Antonio RUIZ LÓPEZ \\ Ana Ma RUIZ GÓMEZ \\ Francisco A. ARAQUE ARANDA (*)
}

El norte de la provincia de Córdoba conforma un marco de enorme interés para el análisis de los primeros momentos de la metalurgia en Andalucía Occidental dada la excepcional riqueza en recursos mineros, y muy especialmente cupríferos que encierra su subsuelo. A este hecho viene a sumarse su singularidad geográfica como lugar de interrelación entre los desarrollos culturales coetáneos en el valle del Guadalquivir, Extremadura y zona occidental de la Submeseta sur. Conscientes de estos hechos, nos planteamos hace varios años un programa de investigación que, partiendo de una serie de prospecciones sistemáticas, nos permitiera una primera y sólida aproximación a la dinámica del Calcolítico en estas tierras cordobesas, labor que ya ha dado sus primeros frutos (MURILLO, 1986,1986 b, 1987) y en la que debe inscribirse el presente trabajo.

\section{Emplazamiento y características geológicas}

El yacimiento estudiado se ubica en el término municipal de El Viso, a unos mil mts. al oeste de la localidad, en el lugar conocido por La Longuera, extensa zona llana en la actualidad dedicada a huertas. El carácter intensivo de las labores agrícolas aquí desarrolladas explica la enorme abundancia de materiales exhumados, que se concentra en un área de unos $6.000 \mathrm{~m}^{2}$ con centro en la denominada huerta de José Antonio, sin que hallamos podido constatar ningún tipo de estructura habitacional o funeraria. 
Con una altitud de $560 \mathrm{mts}$. sobre el nivel del mar, La Longuera constituye una zona con tierras relativamente aptas para el cultivo, teniendo en cuenta la escasez de suelos agrícolas que presentan Los Pedroches. Junto a ello los mayores alicientes para el asentamiento humano serían la abundancia de recursos acuíferos y la existencia a unos $800 \mathrm{mts}$. al norte, de afloramientos cupríferos, como el de La Almagrera, donde hemos recogido fragmentos cerámicos idénticos a los de La Longuera y un gran "martillo" de minero.

Morfológicamente La Longuera se sitúa en el sector central de Los Pedroches, amplia franja de orientación NO-SE caracterizada por un relieve muy plano, típico de penillanura, tan sólo accidentado por suaves lomas de gran radio de curvatura (VALLE BUENESTADO, 1983). En cuanto a la litología de la zona, está formada por un roquedo intrusivo, fundamentalmente de granodiorita y adamellita (CABANAS, 1973), datables en la fase Astúrica del plegamiento Herciniano. Especial interés tienen una serie de diques y filones que con dirección NO-SE surcan el batolito pedrocheño, pues constituyen concreciones metalíferas de naturaleza cuprífera, plumbífera o ferruginosa. Además, cuando se presentan diaclasados, suministran caudales acuíferos de cierta consideración, hecho que explica que la totalidad de los núcleos de población de Los Pedroches se ubiquen en las cercanías de estos filones, en los puntos de contacto entre materiales intrusivos y sedimentarios (VALLE BUENESTADO, 1983).

Estudio de los materiales

El conjunto de materiales estudiados procede de diversas prospecciones realizadas por nosotros mismos, así como de las colecciones conservadas en la "Peña Cultural de los Reyes Magos" de El Viso (1).

Dada la abundancia de material hemos debido proceder a una necesaria selección, recogiendo en la parte gráfica de este trabajo fundamentalmente las formas reconstruibles y una muestra de los restantes tipos. Todo ello lo hemos reunido en grandes grupos tipológicos que permitirán una mayor comprensión de las características industriales de La Longuera. En total hemos analizado 688 piezas, de las cuales el 11 ' $33 \%$ corresponden a la industria lírica (7'7\% sílex y 3'63\% piedra pulimentada), el 0' $14 \%$ al grupo de útiles metálicos, el 80 '66\% al grupo cerámico y el 6'83\% al grupo de varios.

(1) Debemos agradecer a D' Ana M' Vicent y a D. Alejandro Marcos, ex-conservadores del M.A.P.CO. las facilidades dadas para el estudio de los materiales allí depositados, así como a los directivos de la "Peña Cultural de los Reyes Magos" y a D. Francisco Valverde, por haber puesto a nuestra disposición sus colecciones particulares. 


\section{Industria lítica}

Incluye dos grandes conjuntos representados por el sílex y la piedra pulimentada. Respecto al primero se utiliza como materia prima un sílex color gris crema, negruzco y blanco, que en el 9'43\% de las piezas estudiadas ha sufrido la acción del fuego. Se trata de una industria eminentemente laminar ( 83 ' $87 \%$ del total de productos de talla) en la que las piezas completas sólo representan el 23'07\%; el córtex está presente en el 2'56\% y el talón en el 20'52\% (liso, puntiforme o facetado), en tanto que sólo el 17'94\% conservan el bulbo. En lo referente al retoque (presente en el 79'48\% de las piezas), destaca el abrupto (51' $28 \%$ ), seguido del plano (20'51\%), simple (17'94\%) y sobreelevado (10' $25 \%)$, en su mayorparte directo (46'15\%) o inverso (15'38\%), en tanto que el bifacial, mixto y alterno aparecen con porcentajes menores $(12 * 82 \%, 10 ' 25 \%$ y 5 ' $12 \%$ respectivamente).

Los útiles están escasamente representados, limitándose a 4 puntas de flecha, de base cóncava (fig. 2, núm. 1,2 y 3) o recta (fig. 2, núm. 5), a un trapecio (fig. 2, núm. 4) y a un raspador en extremo de hoja retocada (fig. 2, núm. 7). Especial interés presenta la pieza núm. 6 de la fig. 2, hoja con retoque plano bifacial y dos truncaduras rectilíneas en sus extremos. Morfológicamente muestra similitud con el' 'rectángulo", lámina con dorso, bitruncada, con retoque abrupto y al menos un borde sin retocar (MERINO, 1980:188). En la Cova de L'Or están bien representados, aunque aquí con la peculiaridad de no mostrar retoque en ninguno de los bordes (salvo alguno muy marginal, de uso) y de asociar el retoque en doble bisel en algunas de las truncaduras (CABANILLES, 1984; fig. 8). Estas piezas aparecen en Or sólo en los niveles superiores, fechándose en los momentos finales del Neolítico o inicios del Calcolítico (CABANILLES, 1984: 78). Quede claro que tipológicamente la pieza de La Longuera no puede ser clasificada como rectángulo clásico, si bien laposesión de las truncaduras rectilíneas afrontadas, una de ellas obtenida mediante el doble bisel, constituye un elemento de peso para buscar una cierta relación con aquellos.

Los restantes tipos están bien constatados en ambientes calcolíticos similares al aquí estudiado. Las puntas de base cóncava o recta hacen su aparición en el Calcolítico, tal y como se advierte en las estratigrafías de Nerja (ACOSTA-CRUZ AUÑON, 1981: 326327) y Cueva Chica de Santiago (ACOSTA-CRUZ AUÑON, 1981:327). En Papauvas se documentan dentro de un Calcolítico Antiguo (MARTIN DE LA CRUZ, 1985: v. gr. figs. 87-100), en tanto que en Montefrío, donde son muy escasas, aparecen únicamente en estratos del Calcolítico Pleno (ARRIBAS-MOLINA, 1978: figs. 79 y 85). En las vecinas tierras de Ciudad Real y Badajoz las puntas de base recta o cóncava también están presentes, en yacimientos como Vega de los Morales (VALLESPI et alii, 1985: láms. 46; 13-26, y 21), El Lobo (MOLINA LEMOS, 1977) o Pijotilla (HURTADO, 1980). En el norte de la provincia de Córdoba constituyen un tipo frecuente presente en poblados como Los Castillejos (MURILLO, 1986 b: fig. 6) y El Peñón (MURILLO, 1987 e.p.: fig. 
2), y en los sepulcros megalíticos de La Sierrezuela, las Almagreras, la Atalay uela, Venta Alhama, El Minguillo, Peñón de las Aguilillas, etc. (MURTLLO, 1986:256 y ss.).

Los trapecios son útiles relativamente frecuentes en yacimientos calcolíticos, principalmente en sepulcros (LEISNER, 1943 y 1965). En hábitats los encontramos en Papauvas (MARTIN DE LA CRUZ, 1985: fig. 97), Montefrío (ARRIBAS-MOLINA, 1978: fig. 28), Cueva Chica de Santiago (ACOSTA-CRUZ AUÑON, 1982:325), Vega de los Morales (VALLESPI et alii, 1985: láms. 4 y 11), Sierra Palacios (GAVILÁN, 1986) y El Peñón (MURILLO, 1987 e.p.: fig. 3).

La presencia de núcleos agotados y de restos de talla documenta la fabricación in situ de todas estas piezas.

La industria lítica pulimentada está bien representada en el yacimiento; como materia prima suele emplearse fundamentalmente la granodiorita, el granito y una variedad de arenisca. Los tipos existentes se limitan a hachas (fig. 3, núm. 19) y azuelas (fig. 3, núm. 17) de diversos tamaños, algunas muy pequeñas, de carácter más bien votivo que funcional (fig. 3, núm. 15), manos de mortero, martillos y mazos de minero (fig. 3, núms. 16 y 18) y molinos naviformes con sus correspondientes manos, así como el fragmento de un posible recipiente. Estos tipos constituyen indicadores cronológicos de poco valor, por cuanto presentan una amplia cronología que, para la mayor parte de ellos, oscila desde el Neolítico a época protohistórica, si bien es, posiblemente, durante el Calcolítico cuando alcanzan una mayor difusión. No obstante, tienen el interés de atestiguar la existencia de determinadas actividades económicas, como el cultivo de cereales (molinos) y la minería (martillos de minero).

\section{2. Útiles metálicos}

Fabricado en metal sólo contamos con un útil, una hacha plana de cobre, fracturada por la zona del talón, con bordes rectilíneos y filo arqueado, ligeramente desarrollado respecto a aquellos (fig. 4). La sección transversal es rectangular, con la peculiaridad de ser más delgada en el centro que en los extremos, hecho que determina que ambas caras adopten un perfil levemente cóncavo. Además de este ejemplar tenemos noticias de la aparición en La Longuera de, al menos, otra hacha plana, cuyo paradero actual desconocemos.

Este tipo metálico es poco frecuente en los contextos calcolíticos andaluces, donde no se constatan en ninguno de los hábitats excavados. Tan solo podemos señalar la presencia de una de estas hachas entre los materiales de superficie procedentes del Caserío de Morales, en Castro del Río (CARRILERO et alii, 1982: fig. 14), yacimiento encuadrable en un momento temprano del Calcolítico a juzgar por la abundancia de fuentes carenadas. En Portugal, sin embargo las hachas planas son muy frecuentes en yacimientos del llamado Horizonte de las Colonias, y singularmente en VNSP (JALHAY-DO PACO, 
1945: láms. XVn-XVTII) y Zambujal (SCHUBART-SANGMEISTER, 1984:32).

En contextos funerarios las tenemos documentadas en Zarcita (CERDAN-LEISNER, 1952) y en varios sepulcros almerienses, como Millares 5, Almizaraque, Atalaya 6 , Rambla deHuécharoLasPeñicas(LEISNER-LEISNER,1943:523).En el SE, las hachas planas constituirán un tipo frecuente en época argárica (LULL, 1983:178 ss.), en tanto que en las regiones suroccidentales de la Península aparecerán con mayor frecuencia en los momentos tardíos del Calcolítico dentro del Horizonte de Ferradeira (SCHUBART, 1971:24 ss.) y en el mundo de las cistas del Bronce del SO (SCHUB ART, 1975), cuyas prolongaciones andaluzas alcanzan las provincias de Huelva (AMO, 1975) y Sevilla (FERNANDEZ et alii, 1976) así como la Baja Extremadura (GIL MASCAREL et alii, 1986).

\section{Cerámica}

\subsection{Cerámica decorada}

Representa un bajísimo porcentaje dentro del conjunto cerámico limitándose a una docena de fragmentos. Las características técnicas son similares a las que veremos en la cerámica no decorada, dominando las superficies alisadas o alisadas finas, el fuego reductor o al temo y el desgrasante medio. Respecto a la forma de los vasos se trata de tipos derivados de la esfera, hemiesféricos (fig. 5) o globulares (fig. 6). Especial interés cronológico tienen los dos fragmentos de campaniforme de la figura 5, que constituyen los primeros constatados hasta el momento en Los Pedroches. El primero (fig. 5, núm. 21) corresponde a un pequeño cuenco hemiesférico decorado con dos bandas de líneas oblicuas, de derecha a izquierda, limitadas por líneas horizontales y realizadas mediante impresiones de peine. El segundo también pertenece a un cuenco hemiesférico, aunque de tamaño sensiblemente mayor, presenta dos bandas de líneas quebradas rellenas de trazos verticales, delimitadas por series de tres líneas horizontales, todas ellas ejecutadas mediante incisiones (fig. 5, núm. 22).

Varios fragmentos presentan decoración incisa, consistente bien en simples líneas horizontales (fig. 6, núm. 23 y 24) bien en un tema más complejo con bandas delimitadas por incisiones ligeramente oblicuas de derecha a izquierda, y rellenas por líneas transversales paralelas (fig. 6, núm. 25). Características especiales ofrece el fragmento 29 de la figura 6, perteneciente a un vaso globular cerrado con las superficies de color negro, alisadas finas y una decoración consistente en trazos oblicuos dispuestos en torno a un eje central, a modo de espiga invertida, todos ellos realizados mediante suavísimas acanaladuras que apenas inciden en la superficie del vaso, consiguiendo un efecto muy parecido al que, en el Bronce Final, observamos en la decoración bruñida. Este motivo es relativamente frecuente en Portugal, dentro de la cerámica decorada del Horizonte VNSP 
I (BLANCE, 1971;lám. 15).

Completan el conjunto de la cerámica decorada seis fragmentos a la almagra (fig. 6, núms. 26-28). Se trata de "aguadas" de poca calidad y consistencia aplicadas generalmente a la superficie externa del vaso, aunque en ocasiones se de también en el interior. El color es rojo claro o rojo anaranjado.

La cerámica campaniforme está presente en numerosos yacimientos andaluces, encuadrados en un momento del Calcolítico Final o Millares II. Su porcentaje respecto al conj unto del material cerámico es siempre escaso, no alcanzando el $10 \%$ ni tan siquiera en un poblado como el Cerro de la Virgen, en el que aparece en gran cantidad. Los hallazgos de campaniforme más próximos a La Longuera son los procedentes de diversos poblados y sepulcros del valle del Guadiato. Campaniforme impreso de tipo marítimo lo encontramos en Los Castillejos de Fuente Ovejuna, y de tipo geométrico en el enterramiento de La Retuerta y en el dolmen de La Sierrezuela. En cuanto al campaniforme inciso lo encontramos en El Peñón y en La Calaveruela (MURILLO, 1986 y 1986 b). Estos yacimientos, unidos a los recientemente localizados en la Campiña cordobesa (RUIZ LARA, 1985) y en la provincia de Badajoz (ENRIQUEZ NAVASCUES-IÑESTA, 1985) constituyen un importante elemento a tener en cuenta a la hora de analizar la problemática campaniforme en el Suroeste español.

Para la posición cronológica de los diferentes tipos campaniformes son fundamentales las observaciones realizadas en Montefrío, donde, una vez superada la discrepancia que en las diversas publicaciones se observa en la atribución cultural de los niveles, se confirma la cronología propuesta por H ARRISON (1977), con presencia de campaniforme de tipo marítimo ya desde estratos equiparables a los V a-IV b del Corte I (ARRIBAS-MOLINA, 1978:133, nota 37), campaniforme impreso de tipo geométrico en los estratos IV b-IV a, e inciso a partir del III, fechado C-14 en 1865 \pm 35 a.C. (ARRIBAS-MOLINA, 1977:396 ss.).

La cerámica de la almagra, ya presente en el Neolítico Antiguo de Carigüela, alcanzará su máximo auge en el Neolítico Medio y Final, para perdurar durante el Calcolítico y alcanzar, más o menos degenerada, el Brnce Tardío y Final, como observamos en Cerro del Real y Cerro de la Encina. En Montefrío la almagra está documentada en los estratos correspondientes al Neolítico Final, Calcolítico Inicial y Calcolítico Final del corte I (ARRIBAS-MOLINA, 1978). En Andalucía Occidental la encontramos en Papauvas (MARTIN DE LA CRUZ, 1985: 188), Valencina de la Concepción (FERNANDEZOLIVA, 1986:29y31), Huerta del Caño y Arroyo del Tamujar (MURILLO, 1986:278).

Motivos decorativos incisos los hallamos en el Calcolítico Inicial de Montefrío (ARRIBAS-MOLINA, 1978), Papauvas (MARTIN DE LA CRUZ, 1985: figs. 45,49 y 55), El Canjorro (CARRASCO-MEDINA, 1983) y El Lobo (MOLINA LEMOS, 1977). En Córdoba también los encontramos en El Peñón, El Minguillo (MURILLO, 1986) y Caserío de Morales (CARRILERO et alii, 1982). 


\subsection{Cerámica no decorada}

Representa el conjunto más importante de la industria de La Longuera (80\% del total). Los bordes constituyen el 65*76\%, seguidos de atípicos (26'09\%), galbos (3'4\%), SPS $\left(0^{*} 7 \%\right)$, arranques de cuello ( $\left(0^{\prime} 5 \%\right)$ y bases $\left(0^{\prime} 36 \%\right)$. En el acabado de las superficies se observa un neto predominio de las alisadas y alisadas toscas, con casi el $80 \%$ del total, en tanto que los tratamientos muy buenos (bruñidos, espatulados y alisados muy finos) se encuentran mínimamente representados. En relación con los principales grupos tipológicos, debemos señalar un mejor tratamiento de las superficies interiores (alisadas finas o alisadas) de platos y fuentes, frente a las exteriores (alisadas o alisadas toscas). Contrariamente en los vasos globulares cerrados se aprecia un mejor tratamiento de la superficie exterior, al tiempo que es aquí donde se emplean las mejores calidades.

El fuego de cocción predominante es el reductor (49'72\%), seguido del alterno (20'44\%), oxidante (19'52\%) y nervio de cocción $(10 * 31 \%)$. Los colores son medios (pardos, marrones, grises), en algunos oscuros y rarísimos claros. En cuanto al desgrasante, domina el grueso y el medio estando poco representados los muy gruesos, finos y muy finos (fig. 7). Normalmente se emplea cuarzo y mica, así como minúsculas gravillas. Las paredes suelen ser gruesas, seguidas de las muy gruesas y los diámetros grandes y muy grandes en platos y fuentes, y grandes y medios en los restantes tipos.

Tipológicamente hemos dividido el material cerámico no decorado de La Longuera en seis grandes conjuntos, en los que agrupamos las siguientes formas.

\section{A. Formas derivadas de la esfera}

Dada la ausencia de vasos de casquete esférico, incluye a los hemiesféricos y a los de más de media esfera. Los primeros están representados por una serie de vasos con un diámetro entre los 120 y 200 mm., aunque no faltan ejemplares mayores (v. gr. fig. 8, núm. 46) y menores (fig. 9, núm. 54). Como SPS sólo poseen algún mamelón de sección elíptica (fig. 8, núm. 48). Los bordes, siempre salientes, son redondeados (v. gr. fig. 8, núm. 49), apuntados (fig. 9, núm. 56), biselados (fig. 8, núm. 47) o ligeramente estrangulados (fig. 8, núm. 45). Las superficies alisadas o alisadas finas.

Dentro de las formas de más de media esfera, hemos distinguido entre globulares abiertas y cerradas. Las abiertas (fig. 8, núms. 34 a 40; fig. 9, núms. 50 y 52) son escasas, caracterizándose por la posesión de un borde recto, redondeado o redondeado-apuntado, lo que le confiere un característico perfil de paredes cilindricas y base convexa (fig. 9, núm. 50). Los diámetros son medianos o grandes, y las superficies suelen presentar un alisado o un alisado fino.

En cuanto a los vasos globulares cerrados, caracterizados por su borde entrante, constituyen el tipo más frecuente dentro de las formas derivadas de la esfera (figs. 10 a 12). 
Se trata en su mayor parte de recipientes con diámetros grandes o muy grandes, con ejemplares que alcanzan más de 500 mm. (fig. 12, núm. 86), mientras que los medianos son escasos y los pequeños inexistentes. Los bordes son por lo general redondeados o redondeado-apuntados, aunque aparecen también los engrosados (v. gr. fig. 12, núm. 84). Los SPS se reducen a mamelones cónicos y que sobresalen del borden (fig. 10, núm. 60) o de sección elíptica (fig. 10, núm. 59). Las superficies suelen presentar un buen tratamiento al exterior, alisado fino generalmente, si bien ocasionalmente encontramos incluso alisadas muy finas y bruñidas. En cuanto a la superficie interior, se le aplica un alisado o alisado tosco, como mucho un alisado fino en algún caso.

Los cuencos hemiesféricos tienen una cronología muy amplia, apareciendo ya en el Neolítico Antiguo y Medio de Carigüela, mientras que en los yacimientos argáricos son una de las formas más comunes. En Montefrío están presentes a lo largo de toda la secuencia (ARRIBAS-MOLINA, 1978), al igual que en Cerro de la Virgen (SCHÜLE, 1980) y en la totalidad de los yacimientos calcolíticos andaluces y portugueses.

Los vasos globulares, tanto abiertos como cerrados, son frecuentes en la Cultura de Almería, donde constituyen una de las formas más comunes (ACOSTA-CRUZ AUÑON, 1981:334). En Andalucía Occidental los encontramos en Campo Real (CRUZ AUÑONJIMENEZ, 1985: 433), Papauvas (MARTIN DE LA CRUZ, 1985: v. gr. fig. 27) y Valencina de la Concepción (RUIZ MATA, 1975: fig. 10) entre otros muchos. En Los Millares y Cerro de la Virgen son raros, mientras que en Montefrío aparecen frecuentemente en los niveles inferiores, haciéndose más escasos en los superiores (ARRIBASMOLINA, 1978:75).

\section{B. Vasos con cuello indicado}

Forman un pequeño grupo tipológico caracterizado por un cuerpo globular, más o menos cerrado, y un borde recto o ligeramente saliente, que configura lo que hemos definido como cuello indicado (fig. 13). Los bordes pueden ser, redondeados (fig. 13, núm. 88), semiplanos (fig. 13, núm. 91), apuntados (fig. 13, núm. 92) o labiados (fig. 13, núm. 95). El diámetro oscila desde el mediano (fig. 13, núm. 87) al muy grande (fig. 13, núm. 88) y el tratamiento de las superficies suele ser bueno, con alisados finos y muy finos.

Vasos de este tipo los encontramos en El Peñón y La Sierrezuela (MURILLO, 1986), así como en otros muchos yacimientos calcolíticos andaluces, aunque no constituyen un item con valor cronológico claro, a diferencia de los ejemplares con cuello claramente diferenciado. 


\section{Fuentes Carenadas}

Representan un tipo muy singularizado que se caracteriza por la posesión de una carena baja o a media altura y por un gran tamaño, que en ocasiones alcanza los $600 \mathrm{~mm}$. de diámetro. De acuerdo con la delineación de las paredes es posible diferenciar tres variantes, según éstas sean rectas (v. gr. fig. 14, núm. 100), cóncavas (v. gr. fig. 15, núm. 115) o convexas (v. gr. fig. 14, núm. 101). Respecto a la carena, contamos con ejemplares en los que se encuentra muy marcada (fig. 14,núm. 102,104 y IOS), en tanto que en otros es mucho más suave (fig. 14,núm. 100; fig. 15,núms. 114y 115). Las bases son convexas en todos los casos, si bien en algunos ejemplares aparecen sensiblemente aplanadas. Los bordes suelen ser redondeados o semiplanos, si bien algunos ejemplares los presentan labiados y ligeramente engrosados al interior (fig. 14, núms. 107 y 108), marcando la transición al tipo de plato o fuente con borde engrosado que veremos a continuación (fig. 14, núms. 109, y 110; fig. 18, núm. 192). Ninguno de los ejemplares analizados presenta SPS. Peculiar resulta la fuente núm. 112 de la fig. 15 , que posee una pequeña zona deprimida a la altura de la carena, donde configura una concavidad. Las superficies presentan un alisado o alisado fino, siendo el alisado muy fino y el alisado tosco poco frecuentes.

\section{Fuentes y platos de borde engrosado}

Constituyen el grupo tipológico mejor representado en La Longuera (figs. 16-22), caracterizado por recipientes grandes (platos) o muy grandes (fuentes) que presentan como elemento singularizador el típico borde engrosado. Respecto al perfil general, hemos distinguido dos subtipos, según presenten o no carena. Esta suele ser más suave que la del grupo anteriormente analizado (fig. 16, núm. 131; fig. 18, núms. 172 y 192; fig. 19, núm. 197; fig. 22, núm. 216) y va siempre asociada a recipientes de un gran diámetro.

El borde, elemento distintivo de este tipo, presenta una enorme variedad morfológica, hasta el punto que resulta difícil encontrar dos ejemplares iguales. No obstante, es posible realizar una clasificación en varios grandes grupos. El primero estaría constituido por los bordes con engrosamiento interior. Es el más numeroso, representando la casi totalidad del material estudiado. Podemos distinguir diversas variantes, desde los típicamente almendrados (v. gr. fig. 16, núms. 122,136 ó 140) a los semicirculares (v. gr. fig. 16, núm. 134) o apuntados (v. gr. fig. 16, núm. 131).

Muy escasos son los bordes con engrosamiento exterior tipo/neo de ave (fig. 18, núm. 183; fig. 20, núm. 212), así como los que presentan engrosamiento tanto exterior como interior, con un perfil en "T" (v. gr. fig. 18, núm. 192).

En el tratamiento de las superficies se observa un mayor cuidado de las interiores, que suelen presentar un alisado o alisado fino, en tanto que las exteriores muestran a menudo 
un alisado tosco. En relación a la idea planteada por algunos investigadores sobre la posible fabricación de estos recipientes con moldes de cestería o de cualquier otro material no hemos podido atestiguar huellas de ello en ninguno de nuestros ejemplares. La ausencia de SPS es total en este tipo, con la única excepción del ejemplar núm. 151 de la fig. 17 que presenta un orificio de suspensión. Como elemento a resaltar solamente cabe mencionar la presencia de una acanaladura lingitudinal sobre el borde de la fuente núm. 116 de la fig. 16.

\section{E. Platos con borde no engrosado o biselado}

Agrupamos en esta categoría a un reducido número de platos y fuentes caracterizados bien por la posesión de un borde simple redondeado (fig. 19, núm. 199), redondeadoapuntado (fig. 20, núm. 208) o semiplano (fig. 20, núm. 207), o bien biselado (fig. 19, núms. 206, 204 y 200). El tratamiento de las superficies es idéntico al ya observado para los especímenes con borde engrosado.

Fuentes y platos son las formas más representativas del Calcolítico andaluz, cuya periodización se ha realizado, en buena parte, atendiendo a ellos. Ya el matrimonio Leisner (1943) señaló que eran tipos característicos de los ajuares funerarios del SO peninsular, en tanto que en el SE eran sumamente raros. En los últimos años, la excavación de yacimientos como Valencina de la Concepción, Montefrío y Papauvas, ha permitido asentar las bases de la evolución de los diferentes tipos. Así de acuerdo con la secuencia de Montefrío, se observa como las fuentes carenadas están ya presentes en la fase II, considerada por los excavadores de transición Neolítico Final-Calcolítico Inicial, para casi desaparecer a comienzos de la fase III, en que son sustituidas por las fuentes y platos de borde engrosado, que a su vez serán reemplazados en la fase IV, Calcolítico Final, por los platos de borde biselado (ARRIBAS-MOLINA, 1978), al parecer característicos de la Cultura de Los Millares, en cuyo ámbito los encontramos en Cerro de la Virgen (SCHÜLE, 1980), El Malagón (ARRIBAS et alii, 1978) y en el propio yacimiento epónimo (ALMAGRO-ARRIBAS, 1963: v. gr. láms. XVIII, XLV, L, LI, LXIV).

La reciente excavación de estos dos últimos poblados ha venido a matizar la no aparición de fuentes carenadas y bordes engrosados en ambientes del horizonte Millares. La estratigrafía del corte 3 de la muralla central de Millares ha proporcionado fuentes carenadas en los estratos más antiguos, en tanto que platos y fuentes carenadas con borde engrosado y saliente aparecen en los medios y superiores. Finalmente los bordes almendrados, sin carena marcada, son propios exclusivamente de los estratos superiores (ARRIBAS et alii, 1979: 91 ss.; figs. 10,12 y 14).

Volviendo a Andalucía Occidental nos encontramos con Papauvas, donde las fuentes carenadas son muy numerosas y de gran variedad tipológica, en un contexto de Neolítico Final-Calcolítico Inicial, en tanto que los bordes engrosados están ausentes (MARTIN 


\section{DE LA CRUZ, 1985:183-184).}

En Valencina de la Concepción aparecen gran cantidad de platos y fuentes de borde engrosado, estando también representados, aunque en una proporción notablemente inferior, las fuentes carenadas (RUIZ MATA, 1975: fig. 7), sinque los excavadores hayan constatado ningún cambio apreciable en los perfiles ni ninguna evolución tipológica en los cortes estratigráñcos realizados, con excepción de una mayor frecuencia de las formas con borde almendrado y carena al exterior, en los niveles más recientes, contemporáneos de la cerámica campaniforme (RUIZ MATA, 1975: pág. 84), lo que contradice parcialmente las observaciones realizadas en la fortificación central de Los Millares. Gran interés para el conocimiento de este yacimiento sevillano tiene la reciente publicación de las últimas excavaciones en él realizadas (FERNANDEZ-OLIVA, 1985), en las que se ha podido documentar un momento inicial, en el nivel inferior del corte $\mathrm{D}$, caracterizado por la presencia exclusiva de fuentes carenadas, sin bordes engrosados, así como su posterior perduración a lo largo de toda la secuencia del poblado, hasta alcanzar plena época campaniforme. Lo mismo cabe decir de los bordes engrosados, que una vez hacen su aparición tienen tal aceptación que se desarrollarán en una enorme proporción, que no disminuirá hasta la etapa campaniforme, por el momento mal definida en Valencina (FERNANDEZ-OLIVA, 1985: pág. 106). El mismo cuadro encontramos en el poblado pacense de El Lobo, con fuentes carenadas y platos de borde engrosado a lo largo de toda la secuencia estratigráfica, advirtiéndose únicamente una acentuación de la carena en el nivel más reciente, y una tendencia a la presencia de carena también en los platos de borde almendrado (MOLINA LEMOS, 1980).

Este hecho viene a matizar la sencuencia evolutiva anteriormente vista en Montef río, así como la fijada para el Algarve y el Alemtejo, donde se distingue un Calcolítico Inicial (Horizonte de Vale Pincel II / Cabeco de Mina), caracterizado por fuentes carenadas y por fuentes con borde engrosado al interior y un Calcolítico Pleno (Horizonte de Monte Novo / Cortadouro / Alcalar), con platos de borde almendrado y sin fuentes carenadas (TAVARES-SOARES, 1977).

Además de en los lugares ya citados, las fuentes carenadas están presentes en varios yacimientos andaluces como los sevillanos de Gilena (MORENO-CONTRERAS ,1981), Campo Real y el Acebuchal (BONSOR, 1899:104 y 107), el malagueño de Morro de Mezquitilla (SCHUBART-NIEMEYER, 1976: lám. 4), el granadino de El Manzanil (FRESNEDA, 1983),el almeriense de Loma de Huéchar 2(LEISNER-LEISNER, 1943: lám. 25, núm. 52), los jiennenses de Cueva de la Sima (CARRASCO-TORRECILLA, 1980: fig. 3), Los Patos (BLAZQUEZ, 1975: fig. 27), Puente Tablas, Cerro de San Marcos y Huerto Berenguer (CARRASCO et alii, 1980), y los cordobeses de Algallarín, Castillo de Azuel, Huerta del Caño y Loma de la Alcarria (MURILLO, 1986:295 ss.).

En cuanto a los bordes engrosados, su distribución es amplísima por lo que nos limitaremos a señalar los hallados en Gilena (MORENO-CONTRERAS, 1981; v. $g r$. fig. 
3), San Bartolomé de la Torre (CERDAN-LEISNER, 1952; lám. XXXIX), Cueva del Vaquero y Cañada Honda 6 (LEISNER-LEISNER, 1943: láms. 66 y 67), La Capüla, Cuevalongay Los Barrancos (RODRÍGUEZ TEMIÑO, 1984: figs. 2,3 y 5), Los Alcores de Porcuna (GONZÁLEZ NAVARRETE-ARTEAGA, 1980), La Pijotilla (HURTADO, 1980) y Sierra de las Hoyuelas (CABALLERO KLINK, 1983: 519), así como en los yacimientos cordobeses de Puente Mocho, Huerta del Caño, La Sierrezuela, Fuente de los Tinajeros, Castillo de Santa Eufemia, Cerro del Ermitaño, Al gallarín, Cerro del Molino, Castillo de Bélmez (MURILLO, 1986), Las Higueras, La Vaquera, La Calaverada, Los Castillejos (MURILLO, 1986 b) y El Peñón (MURILLO, 1987 e.p.).

\section{F. Vasos carenados}

Constituyen un grupo tipológico escasamente representado en La Longuera. Se caracterizan por un cuerpo de tendencia cilindrica (fig. 23, núm. 220) o troncocónica (fig. 23 , núms. 221 y 223), con carena baja. El tratamiento de las superficies es similar al de los restantes tipos estudiados, esto es, alisado o alisado fino.

Vasos de carena baja los tenemos documentados en la fase III de Montefrío (ARRIBAS-MOLINA, 1978: fig. 56). En el Cerro de la Virgen son muy frecuentes durante la fase I (SCHULE-PELLICER, 1963: figs. 1-4), así como en El Malagón (ARRIBAS et alii, 1977). En Los Millares los encontramos tanto en la necrópolis (ALMAGROARRIBAS, 1963: v. gr. lám. XVIII), como en el poblado (ARRIBAS etalii, 1979, fig. 13). En Papauvas representa una forma poco frecuente (MARTIN DE LA CRUZ, 1985: figs. 53,68 y 83), así como en Valencina (RUIZ MATA, 1983: fig. 11). En Portugal son comunes en VNSP I y los yacimientos con él relacionados. Ya en la provincia de Córdoba los documentamos en una cueva artificial de Cabra (GARCÍA, 1983: fig. 4), en Morales (CARRILERO etalii, 1982: fig. 4) y en Algallarín, Loma de las Navazuelas y Huerta del Caño (MURILLO, 1986).

\section{G. Otras formas}

Incluimos en este apartado una serie de formas únicas dentro del conjunto cerámico de La Longuera. Entre ellas debemos señalar un vasito cilindrico de $40 \mathrm{~mm}$. de diámetro, con base plana y el arranque de un SPS, posiblemente un mamelón, por encima de ella. Este tipo de vaso ha sido frecuentemente considerado como crisol, función que en nuestro ejemplar no deja de ser hipotética dada la no presencia de restos de metal en su interior. En Campo Real existe un ejemplar casi idéntico al nuestro (CRUZ AUÑON-JIMÉNEZ, 1985: 431).

Otro vaso excepcional es el número 222 de la fig. 23, con cuerpo lenticular, de carena acusada y cuello desarrollado, que presenta a la altura de la carena una serie de perforacio- 
nes unipolares. Para este tipo apenas contamos con paralelos en contextos calcolíticos andaluces, donde sólo en algunos sepulcros megalíticos almerienses hemos encontrado vasos asimilables, algunos de ellos también con perforaciones en la línea de carena (LEISNER-LEISNER, 1943: láms. 3,4 y 29). Casi idéntico al ejemplar de La Longuera es un vaso procedente del dolmen de La Sierrezuela, así como otro del Anta Grande da Comenda da Igreja, si bien éste con perfil más suave y cuello ligeramente más corto (LEISNER-LEISNER, 1959: lám. 26).

Por último incluimos en este apartado dos grandes muñones pertenecientes a recipientes de tipo "cucharón". El primero apenas conserva más que el trozo inmediatamente adyacente de la cazoleta, caracterizándose por la posesión de una depresión circular de la base del muñón (fig. 24, núm. 32). En cuanto al segundo ejemplar, de tamaño inferior, presenta una serie de perforaciones, que no llegan a atravesar completamente el vaso, tanto en la cazoleta como en el mango (fig. 24, núm. 33). Los ejemplares de La Longuera guardan un cierpo parentesco con el tipo II definido en Montefrío para este recipiente, perteneciente a la fase I e incluible en el Neolítico Final (ARRIBAS-MOLINA, 1978: fig. 24, núm. 54). El origen de estos vasos parece claro en el Neolítico, etapa en la que están presentes en toda Europa, muy especialmente en España (ARRIBAS-MOLINA, 1978: 69 ss.). En ambientes calcolíticos los constatamos en Montefrío, procedentes de las antiguas excavaciones de Tarradell (MORENO, 1982: fig. 36); Cerro de la Virgen, en niveles con campaniforme (SCHULE, 1980: fig. 96, núm. 618; fig. 99, núm. 37); Campo Real (CRUZ AUÑON-JIMENEZ, 1985; pág. 433); Cabeco da Mina y Vale Pincel II (TAVARESSOARES, 1977: figs. 12 y 22) y en los dólmenes portugueses de Alcogulo, Anta da Marquesa, Anta da Heredade dos Gal vóes y Olival da Pega (LEISNER-LEISNER, 1959: láms. 3,4, 34 y 40).

\section{Adorno}

Incluimos en este apartado un objeto de indudable interés y del cual hemos podido verificar su procedencia de La Longuera. Se trata de un torques de paletas publicado por ALVAREZ OSSORIO (1954: pág. 61, lám. XIV), quien ya indicó que procedía de un terreno al NO de El Viso. Consiste en una varilla de oro macizo obtenida mediante martillado con un grosor medio de 4' $5 \mathrm{~mm}$. Se encuentra doblado en " $U$ " y rematado por dos apéndices planos y perpendiculares a la varilla. Su longitud total es de 44'5 cms., y la de los apéndices de 25 y 27 mm.; el peso es de 110 grs. (RUIZ GAL VEZ, 1979:164).

En la Península Ibérica sólo contamos con dos ejemplares del tipo que nos ocupa, procedente uno del tesoro de Caldas de Reyes (RUIZ GALVEZ, 1978) y el otro del dolmen de La Veguilla en Salamanca (PÉREZ MARTIN, 1985: 173).

RUIZ GALVEZ (1979: 164) incluye el ejemplar de Caldas de Reyes en su tercera etapa del Bronce Antiguo del NO, fechándolo entre el 1600 y el 1500 a.C. En cuanto al 
torques de El Viso propuso una fecha de 1700-1600 a.C, en función de los paralelos en torques bretones, que también muestran las características paletas. Su aparición en Córdoba la explica en función de la "proximidad" a los enterramientos campaniformes tardíos de Montilla y Cañada Rosal.

HERNANDO GONZALO (1985: 90) propugna también su vinculación con el fenómeno campaniforme, valorando la asociación del torques de paletas de Bennekon, en Holanda, a un vaso de tipo Veluwe. Esta cronología del Calcolítico Final para el torques de El Viso viene corroborada por dos factores más. En primer lugar, por la aparición del torques de La Veguilla junto a campaniforme inciso tipo Ciempozuelos (PÉREZ MARTIN, 1985:173), y en segundo por la presencia de campaniforme impreso e inciso en La Longuera, lugar del que con toda seguridad procede el torques, muy probablemente como parte integrante del ajuar de una sepultura.

\section{Varios}

Integran este grupo' 'cuernecillos" y placas de arcilla perforadas, ambos bien representados en La Longuera y de los que presentamos una muestra en las figs. 26 y 27.

Los "cuernecillos" constituyen uno de los elementos más definitorios del Calcolítico andaluz y portugués. En Montefrío aparecen en el nivel V b, se hacen más frecuentes en el IV b y desaparecen a partir del IV a (ARRIBAS-MOLINA, 1978:115). En El Malagón son frecuentes en una fase incluible en Millares I (ARRIBAS et alii, 1979: fig. 12). En Papau vas son escasos, aunque están presentes a lo largo de toda la secuencia estratigráfica (MARTIN DE LA CRUZ, 1985). En Valencina de la Concepción también aparecen, aunque sin contexto estratigráfico claro (RUIZ MATA, 1983: fig. 15). Por último, en el sur de Portugal están asociados al Horizonte Monte Novo / Cortadouro / Alcalar, del Calcolítico Pleno, no estando presentes en el Calcolítico Antiguo (TAVARES-SOARES, 1977: 261).

En cuanto a las placas de arcilla perforada, las encontramos en el Calcolítico Inicial de Montefrío (ARRIBAS-MOLINA, 1978: figs. 27 y 68), Papauvas (MARTIN DE LA CRUZ, 1985: figs. 70 y 98) y El Lobo (MOLINA LEMOS, 1977). En el Alemtejo y el Algarve son típicas del Horizonte Vale Pincel II / Cabeço da Mina, de inicios del Calcolítico (TAVARES-SOARES, 1977:figs. 12 y 22). En Los Millares están presentes tanto en el poblado, en niveles precampaniformes (ARRIBAS et alii, 1979: fig. 12 j), como en la necrópolis (ALMAGRO-ARRIBAS, 1963: v. gr. págs. 330 y 348).

Junto a estos tipos debemos incluir el objeto representado en la figura 25 , de forma cónica, hueco, fabricado en cerámica con superficie exterior alisada e interior alisada tosca, nervio de cocción y desgrasante grueso. Se encuentra fracturado en uno de sus extremos, precisamente aquel donde presenta una serie de dos profundas incisiones curvas, dispuestas de modo cóncavo al eje de la pieza. Su valoración nos resulta difícil por 
cuanto no contamos con paralelos exactos. En principio pensamos que podría tratarse de un soporte, interpretación desechada dada su atipicidad respecto al conjunto de soportes calcolíticos, inclinándonos más bien por considerarle un carácter cultural, relacionándolo con los ídolos cerámicos de Valencina de la Concepción (FERNANDEZ-OLIVA, 1980: fig. 9), que presentan un perfil similar, si bien suelen ser macizos y no huecos como el nuestro. No obstante recientemente, se han publicado un par de ellos con una gran perforación vertical, casi idénticos al de La Longuera (FERNANDEZ-OLIVA, 1985: fig. 47, núms. 133 y 134). En cuanto a la decoración no la constatamos en ninguno de los ejemplares de Valencina, aunque recuerda a la que presentan numerosos ídolos-cilindro (ALMAGRO-GORBEA, 1973) y la cabeza de un ídolo antropomorfo de cerámica procedente de Valencina (FERNANDEZ-OLIVA, 1980: fig. 5).

\section{Conclusiones}

De acuerdo con lo visto al analizar el conjunto de materiales procedentes de La Longuera, creemos poder afirmar que nos encontramos ante un yacimiento de enorme interés para el conocimiento del Calcolítico en Los Pedroches. Su emplazamiento en un lugar llano y completamente abierto contrasta con el patrón definido para el poblamiento del Calcolítico en el valle del Guadiato, donde los hábitats se localizan invariablementeen las formaciones calizo-cuarcíticas tipo inselberg que jalonan el curso alto y medio del río, con un magnífico control del territorio circundante y unos territorios de explotación muy definidos (MURILLO, 1986: 328-347). Este hecho, condicionado por las diferencias topográficas entre la Penillanura de Los Pedroches y el valle del Guadiato, nos ha llevado a cuestionar la valoración del factor defensivo en la elección del lugar de habitat en este último ámbito geográfico, máxime cuando, a juzgar por los materiales procedentes de Huerta del Caño, aquél no sufrió alteraciones desde el Calcolítico Inicial al Final. Todo ello, siempre y cuando, no consideremos la posibilidad de la existencia de defensas artificiales en yacimientos del tipo La Longuera, de modo análogo a como se han interpretado ciertas estructuras halladas en poblados como Valencina o La Pijotilla (PELLICER, 1986: 246).

Respecto a las posibles estructuras de habitación existentes, no hemos podido constatar ningún dato positivo, lo cual no nos sorprende dada la intensiva remoción del terreno y la fragilidad de los materiales con los que debieron construirse. En la zona aparece una gran cantidad de piedras de mediano y pequeño tamaño, pacientemente retiradas de los campos de labor y amontonadas en los límites parcelarios, muchas de las cuales podrían haberse utilizado como zócalos de cabanas, completadas con un alzado de entramado vegetal, tapial o adobes, de los cuales hemos podido recuperar varios fragmentos con improntas de fibra vegetal trenzada. Estas técnicas de construcción han sido utilizadas en Los Pedroches hasta hace muy pocos años. 
Sobre las actividades económicas practicadas, poco es lo que podemos conocer a través de una prospección superficial, si bien, indirectamente, podemos deducir algunos datos. Así, la presencia de molinos naviformes nos indica la práctica de una agricultura cerealística, para la cual los terrenos próximos al poblado son aptos, tal y como lo demuestra que en la actualidad se continúe el cultivo de la cebada, en tanto que el trigo estuvo presente hasta mediados de siglo. Respecto a la ganadería no contamos siquiera con datos indirectos, por lo que solamente podemos reseñar la proverbial riqueza en pastos de Los Pedroches y el hecho de que ésta vaya normalmente asociada a la agricultura cerealista. Con todo, es llamativa la ausencia de las típicas' 'queseras", muy comunes en los ambientes calcolíticos y tradicionalmente relacionadas con actividades industriales derivadas de la ganadería.

Por último, la minería está documentada por la presencia de' 'martillos' * y mazas de minero, así como por la existencia de materiales cupríferos en las proximidades del poblado. La presencia de varias hachas planas de cobre no es elemento suficiente para considerar la existencia de actividades metalúrgicas en La Longuera, aunque no lo vemos improbable, máxime si consideramos el recipiente número 51 de la fig. 9 como un crisol.

En cuanto a la cronología del poblado, podemos distinguir una primera fase, del Calcolítico Inicial, caracterizada por las fuentes carenadas como principal elemento tipológico, paralela a la documentada en otros yacimientos del norte de la provincia como Huerta del Caño. La fase siguiente, Calcolítico Pleno, tiene a los platos y fuentes de borde engrosado como fósil guía. En estos momentos el poblado alcanzaría su máxima prosperidad, muy probablemente en relación con las actividades mineras, formando parte de circuitos de intercambio en los que se vería favorecido por su proximidad a las grandes vías naturales que atraviesan Los Pedroches de norte a sur, a través de la ruta que unía Almadén con el Guadalquivir por el Calatraveño, y de este a oeste, cque comunica toda la comarca y la abre a Extremadura.

Finalmente, sobre este pujante horizonte cultural vendría a superponerse el fenómeno campaniforme, como un elemento a todas luces intrusivo pero asimilable. A él iría asociado el enterramiento del cual formaría parte el torques de oro y que nos lleva a un mundo de relaciones septentrionales distintas a las hasta entonces representadas por el resto de Andalucía y especialmente su zona occidental, Portugal y Baja Extremadura, que nos adentra en el complejo mundo del tránsito Calcolítico-Bronce, etapa esta última tan poco conocida en Andalucía occidental.

\section{Bibliografía}

ACOSTA, P. - CRUZ AUÑON, R. (1981): 'Los enterramientos de las fases iniciales en la Cultura de Almería", Habis 12,1981, pp. 275-360. 
ALMAGRO, M. - ARRIBAS, A. (1963): El poblado y la necrópolis megalítica de Los Millares (Santa Fe de Mondújar, Almería), Madrid.

ALVAREZ OSSORIO, F. (1954): Tesoros españoles antiguos en el Museo Arqueológico Nacional, Madrid.

AMO, M. del (1975):' 'Enterramientos en cista en la provincia de Huelva", Huelva Prehistoria y Antigüedad, Madrid.

ARRIBAS, A. - MOLINA, F. (1977): * 'El poblado de Los Castillejos en las Peñas de los Gitanos (Montefrío, Granada). Resultados de las campañas de 1971 -74 ", XIVCM.A., pp. 389-406.

ARRIBAS, A. - MOLINA, F. (1978): El poblado de Los Castillejos en las Peñas de los Gitanos (Montefrío, Granada). Campañas de excavaciones de 1971. El Corte 1. Granada.

ARRIBAS, A. et alii (1978): "El poblado de la Edad del Cobre de El Malagón (Cúllar-Baza, Granada)", CP.Gr., 3, pp. 67-117.

ARRIBAS, A. et alii (1979): "Excavaciones en los Millares (Santa Fe, Almería). Campañas 1978-1979", C.P.Gr.,4,pp. 61-118.

BLANCE, B. (1971): Die Anfánge der Metallurgie aufder Iberischen Halbinsel, Berlín.

BONSOR, G. (1899): Les colonies agricoles pré-romaines de la Vallée du Betis, París.

CABALLERO KLINK, A. (1983): La pintura rupestre esquemática de la vertiente septentrional de Sierra Morena (provincia de Ciudad Real) y su contexto arqueológico, Ciudad Real.

CABANAS, R. (1973): "Geología de Los Pedroches. Comentarios sobre la Hoja Geológica 858", BRA.C, 93, pp. 5-48.

CABANILLES, J.J. (1984): "El utillaje neolítico en sílex del litoral mediterráneo peninsular", Saguntum, 18,1984, pp. 49-102.

CARRASCO, J. - MEDINA, J. (1983):' 'Excavaciones en el complejo cavernícola de El Canjorro (Jaén). Cueva 3", XVI C.N.A., pp. 371 -380.

CARRASCO, J. - TORRECILLA, J.F. (1980): ' 'El conjunto sepulcral eneolítico de la Cueva de la Sima (Castellar de Santisteban, Jaén)", B.I.E.G., 102, pp. 71-91.

CARRASCO, J. et alii (1980): Aproximación al poblamiento eneolítico en el Alto Guadalquivir, Jaén.

CARRILERO, J. et alii (1982): 'El yacimiento de Morales (Castro del Río, Córdoba). La cultura de los silos en Andalucía Occidental", CP.Gr., 7, pp. 171-207.

CERDAN, C. - LEISNER, G. et V. (1952): "Los sepulcros megalíticos de Huelva", Inf. y Mem. de la Com. Gen. Exo. Arq., 26, Madrid.

CRUZ AUÑON, R. - JIMÉNEZ, J.C. (1985):' 'Historiacrítica del antiguo yacimiento de Campo Real (Carmona)", Habis, 16,1985, pp. 417-452. 
ENRIQUEZ, J.J. - IÑESTA, J. (1985): "Notas sobre los poblados calcolíticos de la comarca de Llerena", Homenaje a Cánovas Pesini, pp. 15-23.

FERNANDEZ, F. - OLIVA, D. (1980): "Los ídolos calcolíticos del Cerro de la Cabeza (Valencinade la Concepción, Sevilla)", M.M., 21, pp. 20-44.

FERNANDEZ, F. - OLIVA, D. (1985): "Excavaciones en el yacimiento calcolítíco de Valencina de la Concepción (Sevilla). El Corte CWA.H., 25, pp. 7-131.

FERNANDEZ, F. - OLIVA, D. (1986): "Valencina de la Concepción (Sevilla). Excavaciones de urgencia". Rev. de Arqu., pp. 19-33.

FERNANDEZ, F. etalii (1976): 'Los enterramientos en cistas del Cortijo de Chichina (Sanlúcar la Mayor, Sevilla)", T.P., 33, pp. 351-380.

FRESNEDA, E. (1983): "El poblado prehistórico de El Manzanil (Loja, Granada)", XVI CM.A.,pp. 135-140.

GARCÍA, J. (1983): "Un yacimiento eneolítico en Cabra (Córdoba)", / Congreso de Historia de Andalucía. Prehistoria y Arqueología, pp. 49-51.

GAVILÁN, B. (1986): "Resultados preliminares de un corte estratigráfico en Sierra Palacios (Bélmez, Córdoba)", B.R.A.C., 777, pp. 81-88.

GIL MASCARELL, M. etalii (1986): 'Enterramientos encista de laEdad del Bronce en la Baja Extremadura", Saguntum, 20, pp.9-41.

GONZÁLEZ NAVARRETE, J. - ARTEAGA, O. (1980):' 'La necrópolis de Cerrillo Blanco y el poblado de Los Alcores (Porcuna, Jaén)",N.A.H., 10.

HERNANDO, A. (1983): "La orfebrería durante el Calcolítíco y el Bronce en la Península Ibérica", T.P.,40>PP. 85-138.

HURTADO, V. (1980):' 'Los ídolos calcolíticos de La Pijotilla (Badajoz)", Zephyrus, XXX-XXXI, pp. 165-204.

JALHAY, E.D. - PACO, A. do (1945): 'El castro de Vila Nova de San Pedro", Act. yMen. de la S.E.A.E.P., XX, pp. 1-93.

LEISNER, G. - LEISNER, V. (1943): Die Megalithgraber der Iberischen Halbinsel. I: Der Suden, Berlín.

LEISNER, G. - LEISNER, V. (1959): Die Megalithgraber der Iberischen Halbinsel: DerWestén 112, Berlín.

LEISNER, V. (1965): Die Megalithgraber der Iberisches Halbinsel: DerWesten 1/3, Berlín.

LULL, V. (1983): La cultura de El Algar, Madrid.

MARTIN DÉLA CRUZ, J.C. (1985): "Papa Uvas I. Aljaraque, Huelva. Campañas de 1976 a 1979", E.A.E., 136, Madrid.

MERINO, J.M. (1980): Tipología Lítica, San Sebastián.

MOLINA, L. (1980): "El poblado del BronceldeEl Lobo (Badajoz)",N.A.H., 9, PP. 93-127.

MORENO, M.A. (1982):' 'Los materiales arqueológicos del poblado de Los Castille- 
jos y Cueva Alta (Montefrío) procedentes de las excavaciones de 1946 y 1947", CP.Gr., 7, pp. 235-266.

MORENO, M.A. - CONTRERAS, F. (1981): "Un yacimiento de la Edad del Cobre en Gilena (Sevilla)", CP.Gr., 6, pp. 181-201.

MURILLO, J.F. (1986): 'Eneolítico y Edad del Bronce en el Norte de la provincia de Córdoba", Memoria de Licenciatura, Universidad de Córdoba (inédita).

MURILLO, J.F. (1986):" Nuevos yacimientos calcolíticos en el sector noroccidental de la provincia de Córdoba", Est. Preh. Cord., 1, pp. 77-94.

MURILLO, J.F. (1987):' 'Poblado calcolítico y abrigo con pinturas esquemáticas en el Peñón (Peñarroya-Pueblonuevo, Córdoba)", Corduba Archaeologica, 16, e.p.

PELLICER, M. (1986): "El Cobre y el Bronce Pleno en Andalucía Occidental", Homenaje a Siret, pp. 245-250.

PÉREZ MARTIN, R. (1985): "Hallazgo de un torques de paletos en el dolmen de La Veguilla (Salamanca)", XVII/CJVA, 1985, pp. 171-175.

RODRIGUEZTEMIÑO,I.(1984): "El Eneolítico de la Vega de Carmona: aplicación de un modelo de gravedad", Habis, 15, pp. 283-307.

RUIZ MATA, D. (1975): "Cerámicas del Bronce del poblado de Valencina de la Concepción", M.M., 16,1975, pp. 80-110.

RUIZ MATA, D. (1983): "El yacimiento de la Edad del Bronce de Valencina de la Concepción (Sevilla) en el marco cultural del Bajo Guadalquivir", Actas del l CHA., Prehistoria y Arqueología, Córdoba, pp. 183-208.

RUIZ GAL VEZ, M. (1978): "El tesoro de Caldas de Reyes", T.P., 35, pp. 173-192.

RUIZGALVEZ.M. (1979): "El Bronce Antiguo en la fachada atlántica peninsular: un ensayo de periodización", Tf., 36, pp. 151-172.

SCHUBART, H. (1971): "O Horizonte de Ferradeira", Rev. de Guim., LXXXI, pp. 189-216.

SCHUBART, H. (1975): Die Kultur der Bronzezeit im Sudwesten der lberischen Halbinsel, Berlín.

SCHUBART, H. - SANGMEISTER, E. (1984):' 'Zambujal. Un asentamiento fortificado de la Edad del Cobre en Portugal", Rev. de Arqu., 37, pp. 20-33.

SCHÜLE, W. (1980): Orce und Galera.

SCHÜLE, W. - PELLICER, M. (1963): "El Cerro de la Virgen", EA.E., 46.

TAVARES, C. - SOARES, J. (1977): "Contribucao para o conhecimiento dos povoados calcolíticos do Baixo Alemtejo e Algarve", Setubal Arqu., II-III, pp. 179-272.

VALLE BUENESTADO, B. (1983):' 'Los Pedroches", Tesis Doctoral, Universidad de Córdoba (inédita).

VALLESPI, E. et alii (1985): 'Materiales del Neolítico Final-Eneolítico de la Vega de los Morales (Aldea del Rey, Ciudad Real)", Museo de Ciudad Real, Estud. y Monogr., 15, Ciudad Real. 


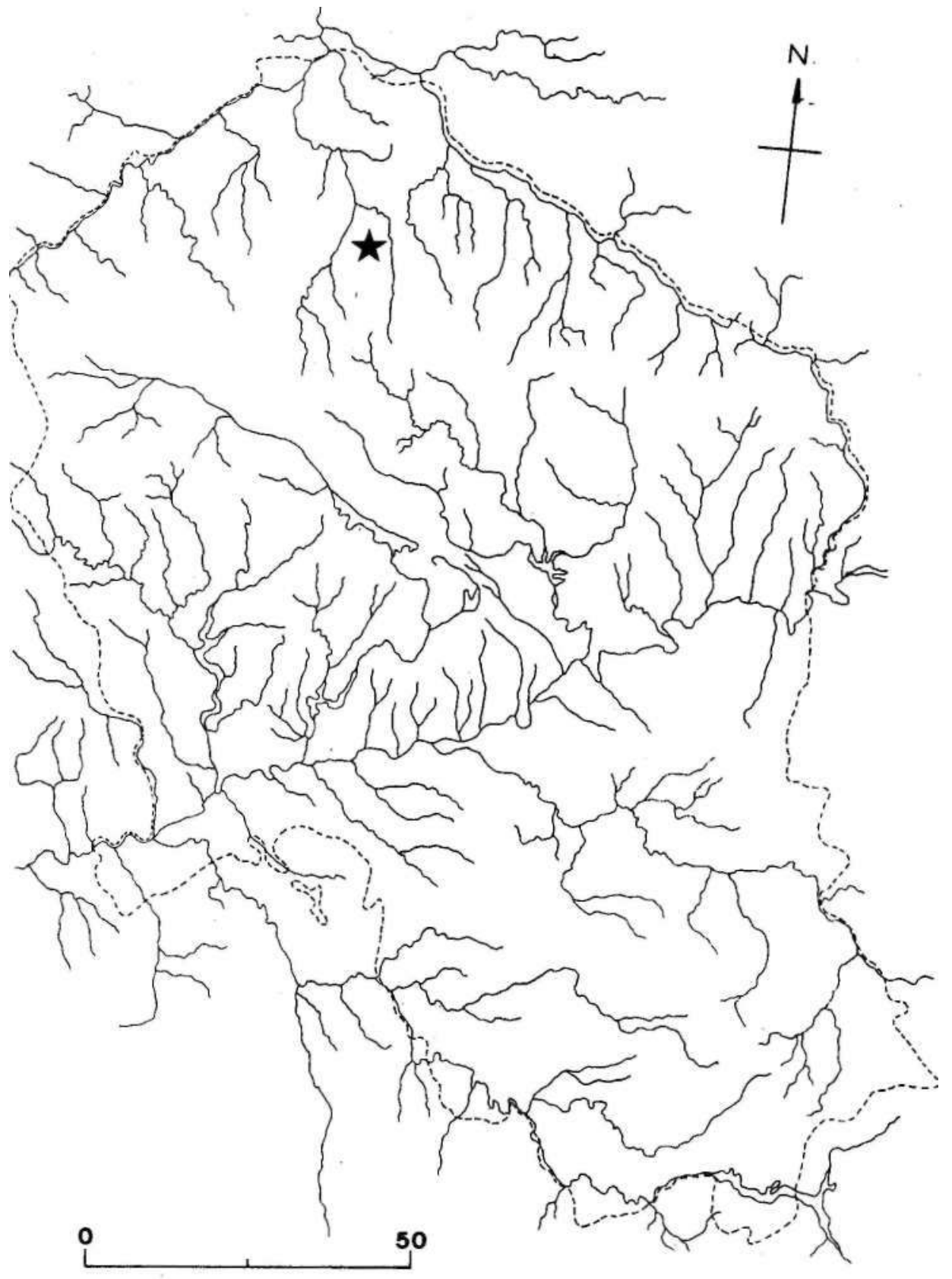

Fig. 1 

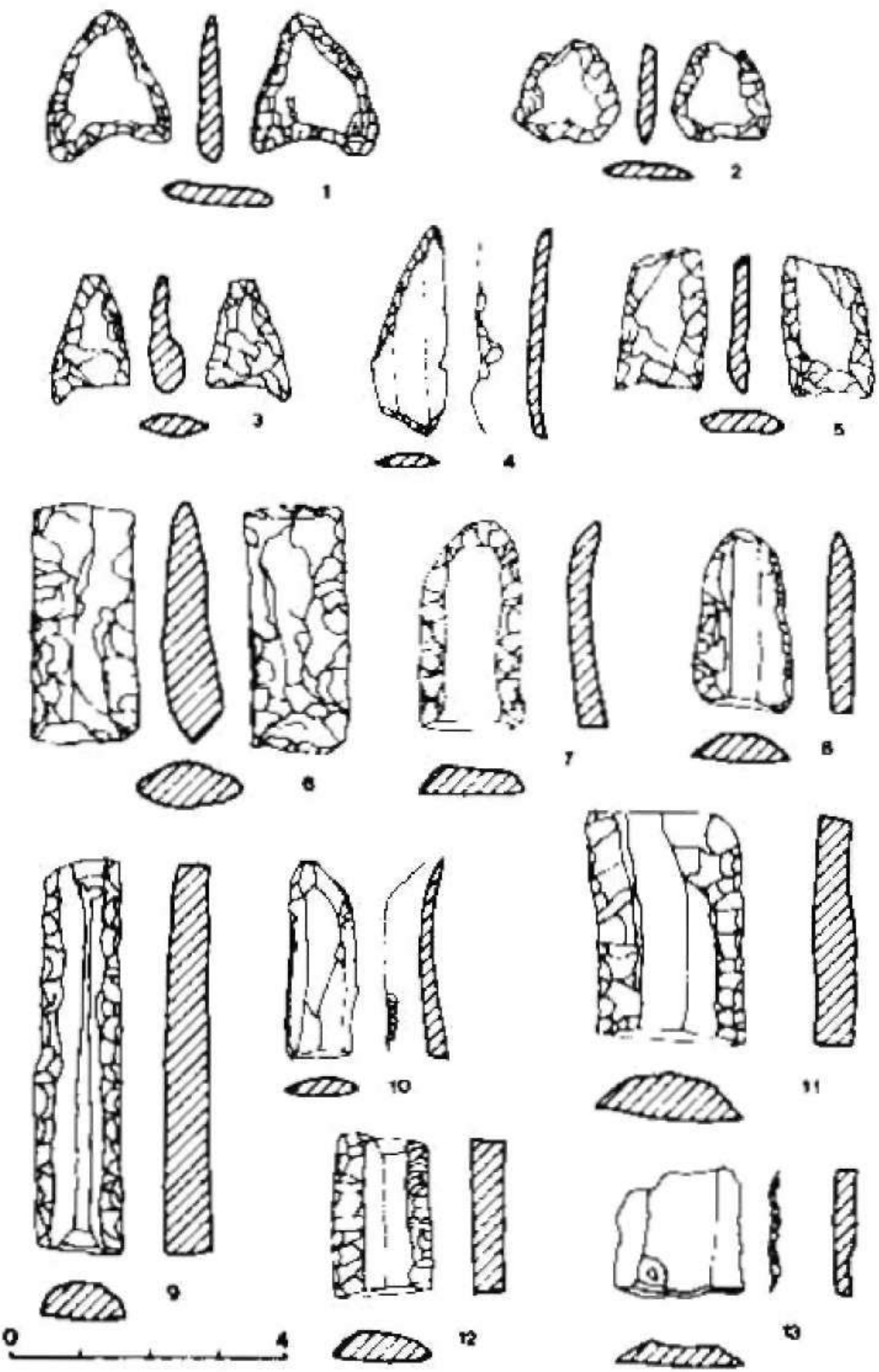

Fì. 2 

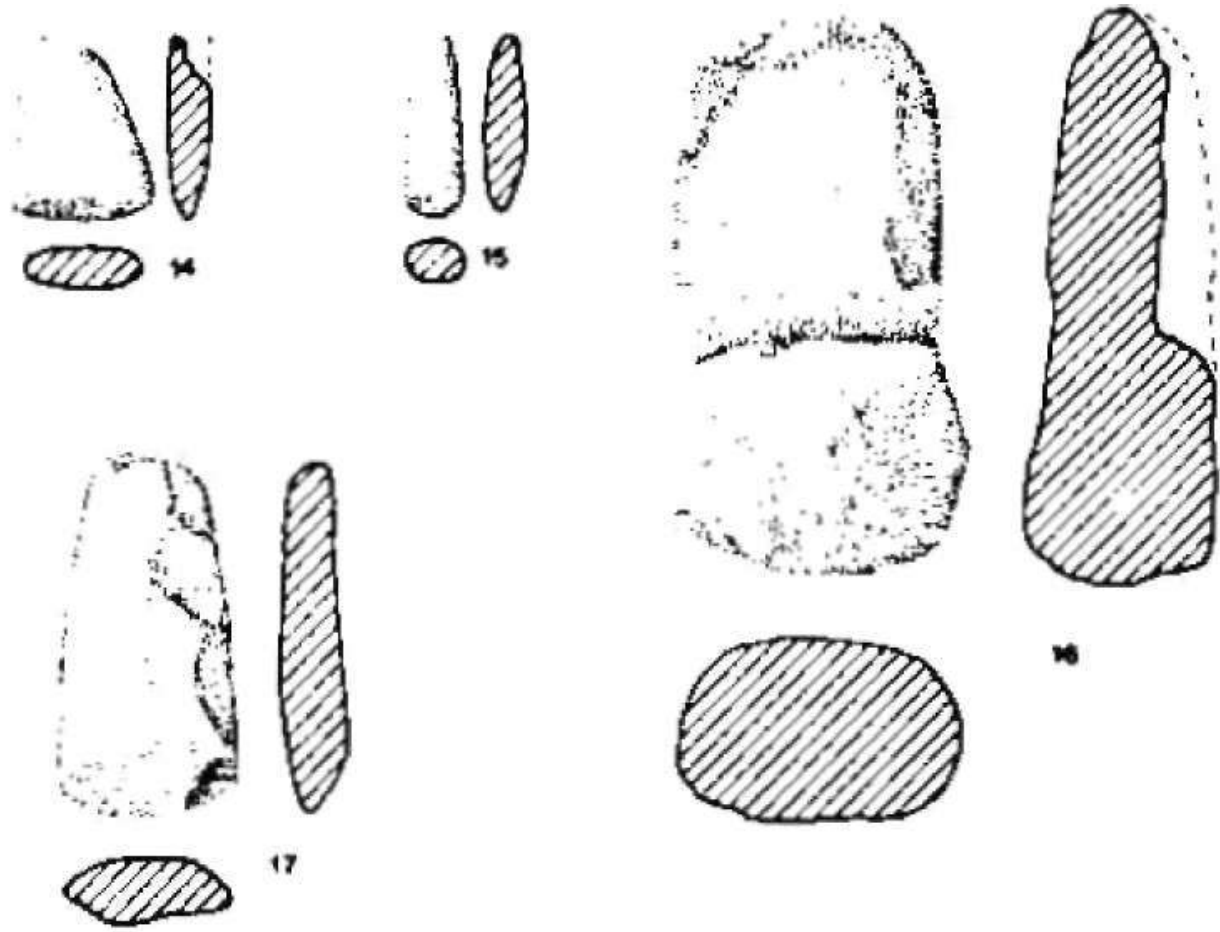

w
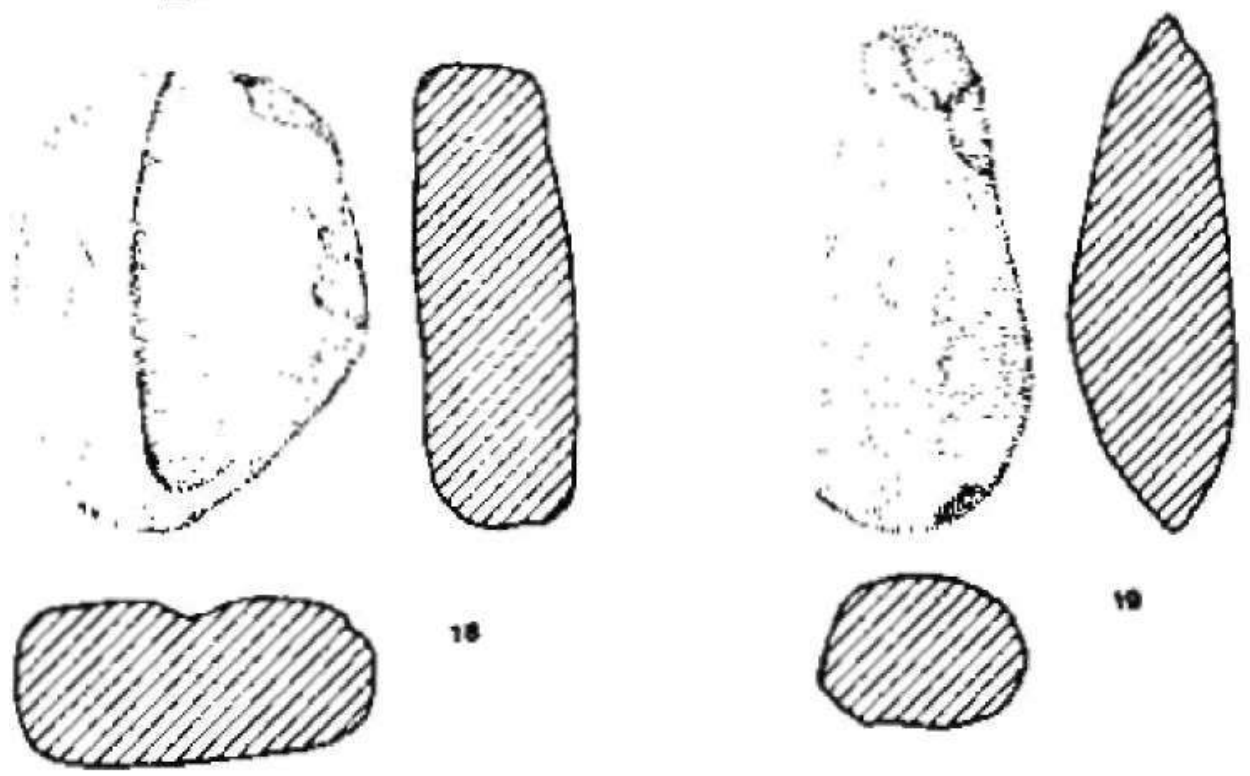

เอ

18
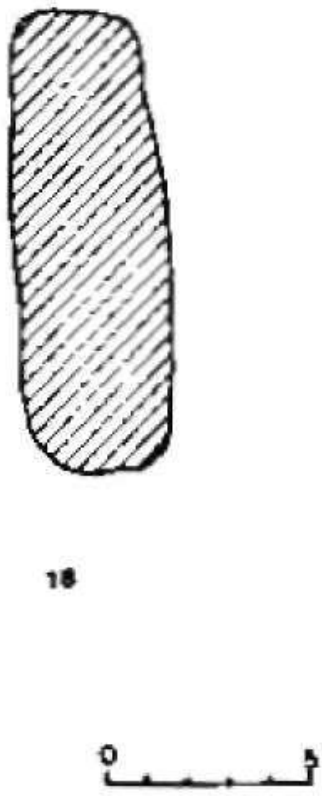

Fig. 3 

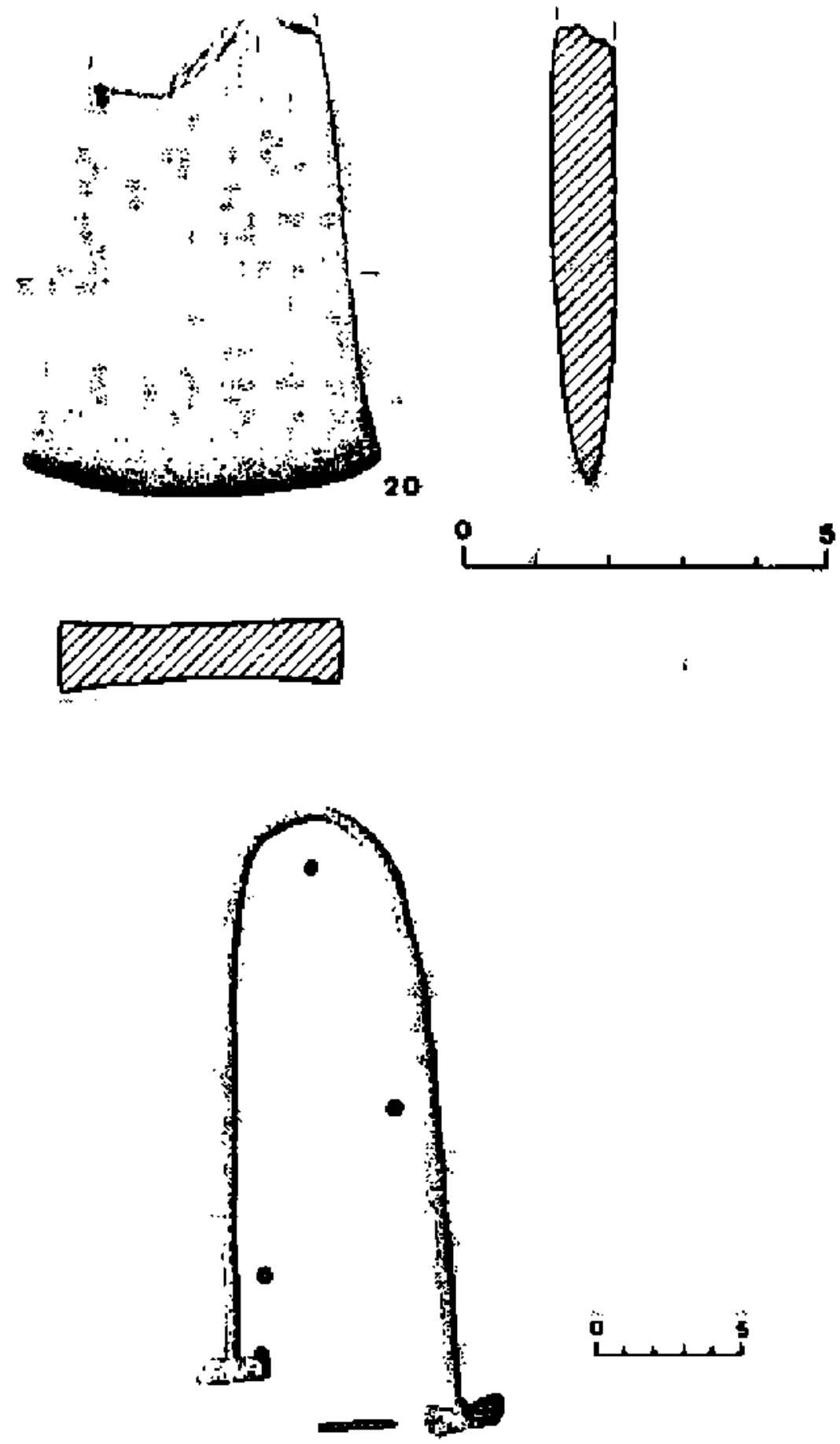

Pig. 4 

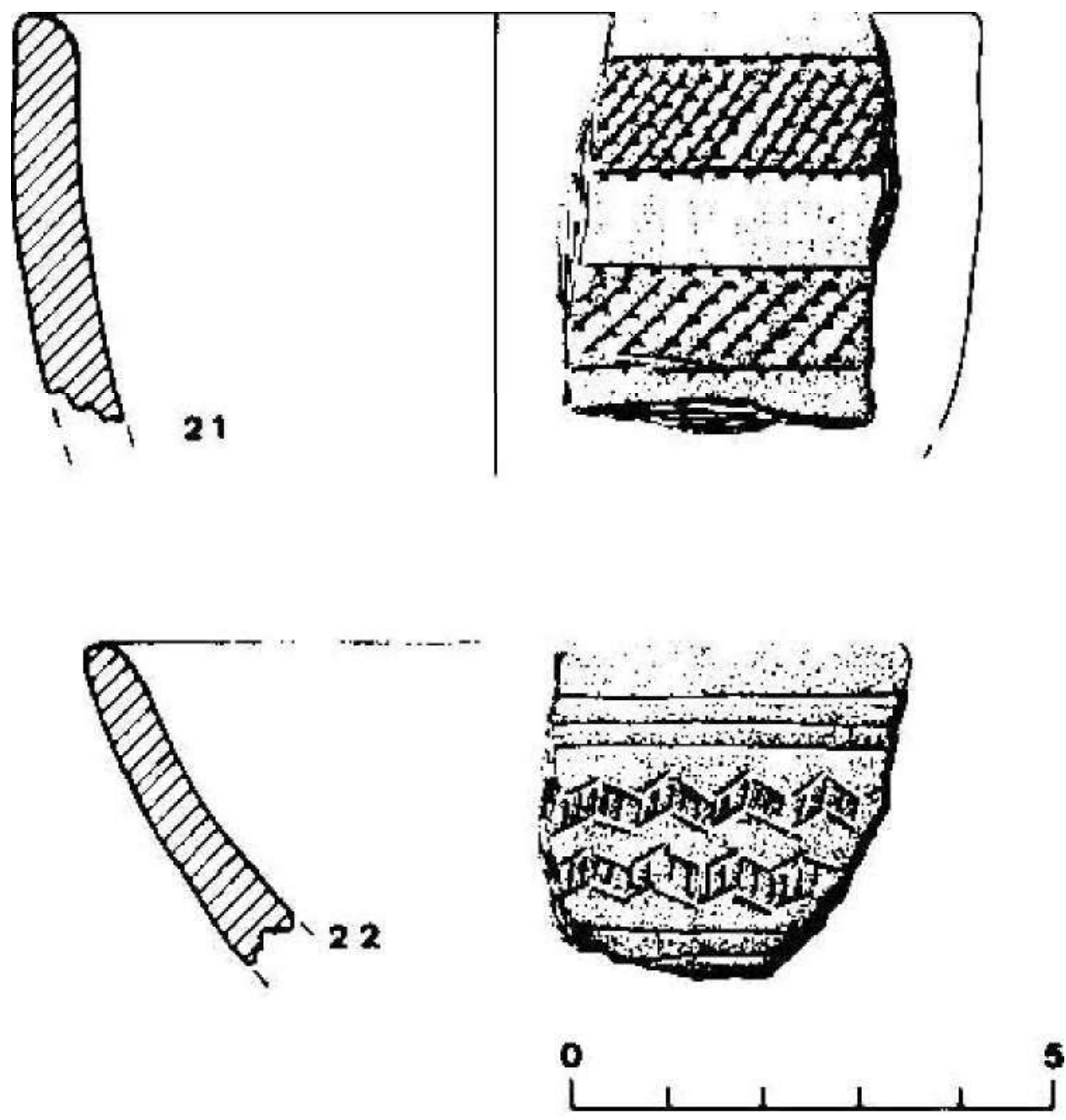

Fire. 5 

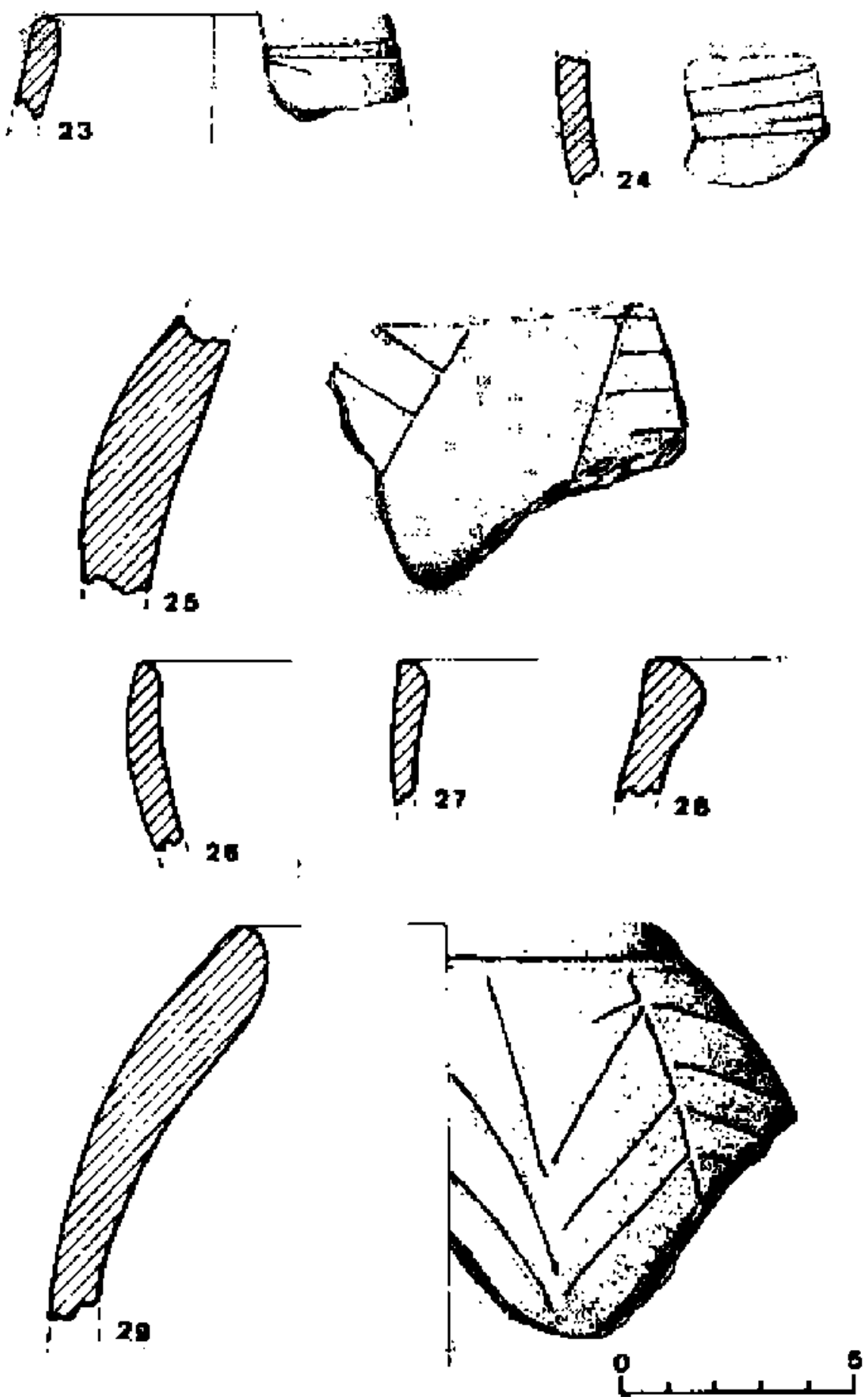

Fins.

77

--- Grupo de investigación P.A.I. HUM 236 | http://www.arqueocordoba.com/publ/anales.htm --- 

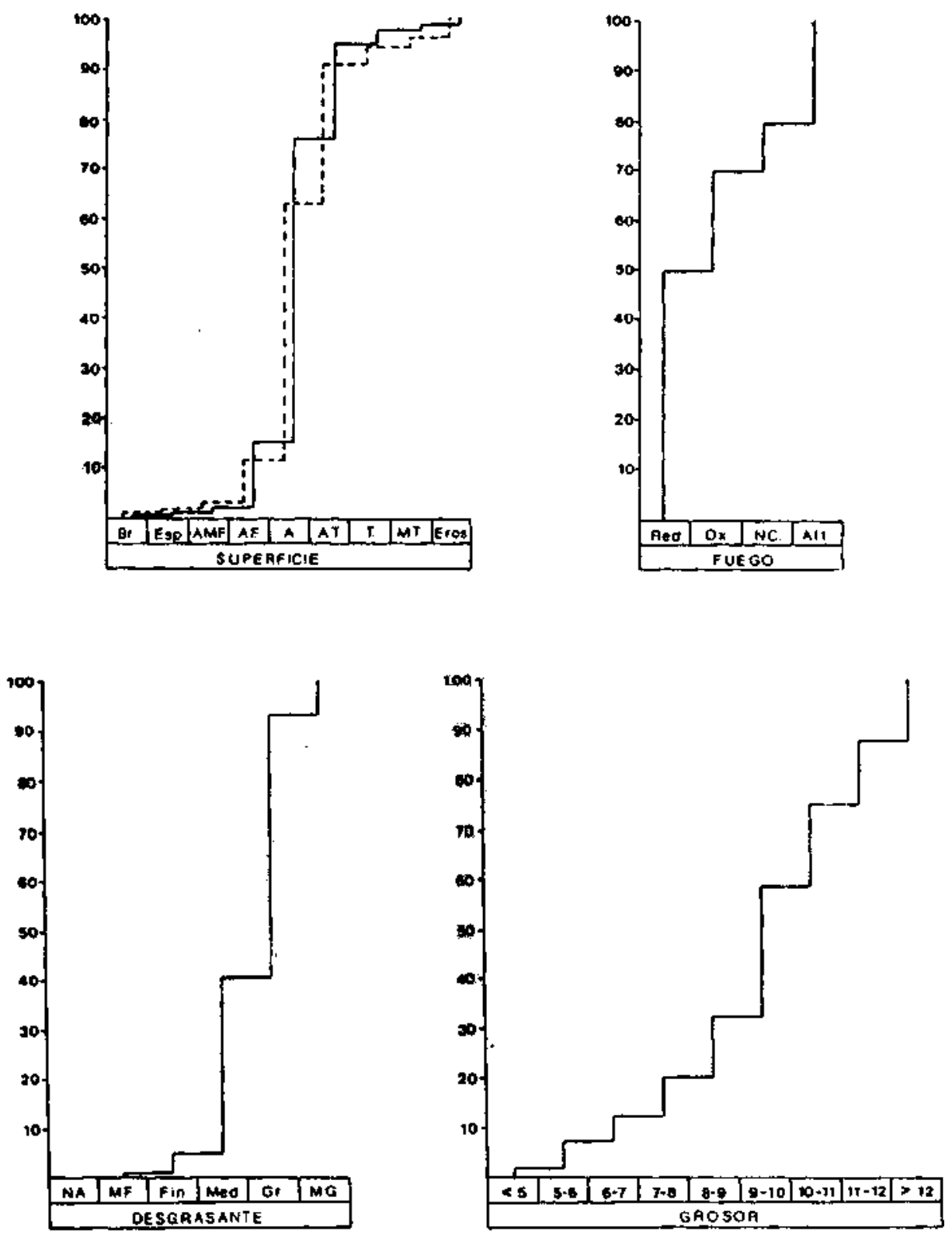

Fig. 7

78

--- Grupo de investigación P.A.I. HUM 236 | http://www.arqueocordoba.com/publ/anales.htm --- 


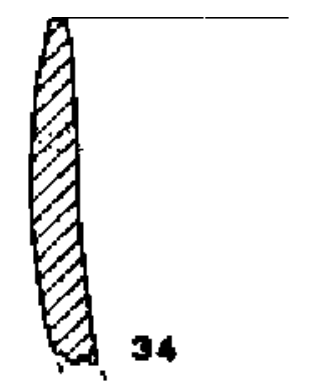

36
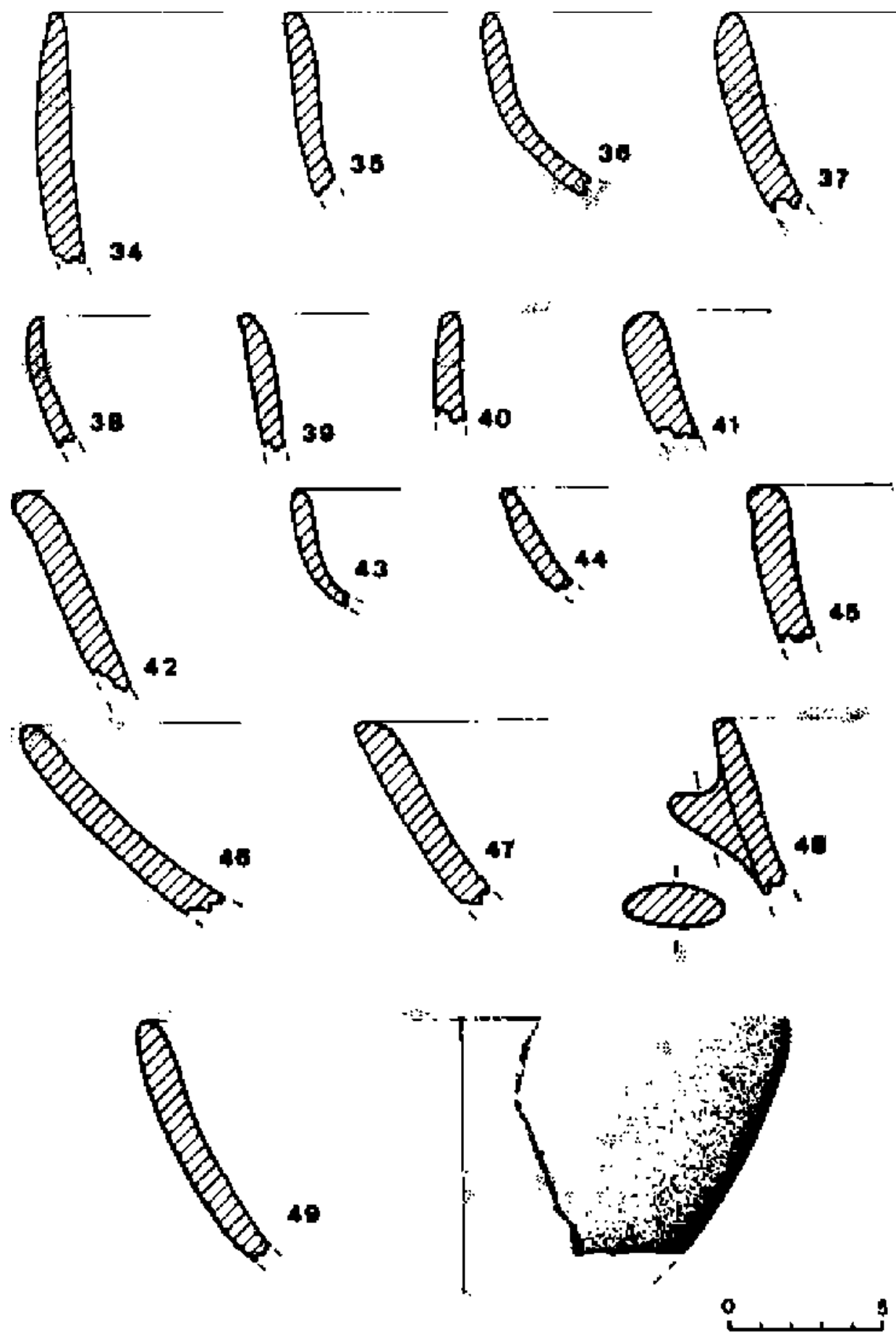

Fit.

--- Grupo de investigación P.A.I. HUM 236 | http://www.arqueocordoba.com/publ/anales.htm ---79 

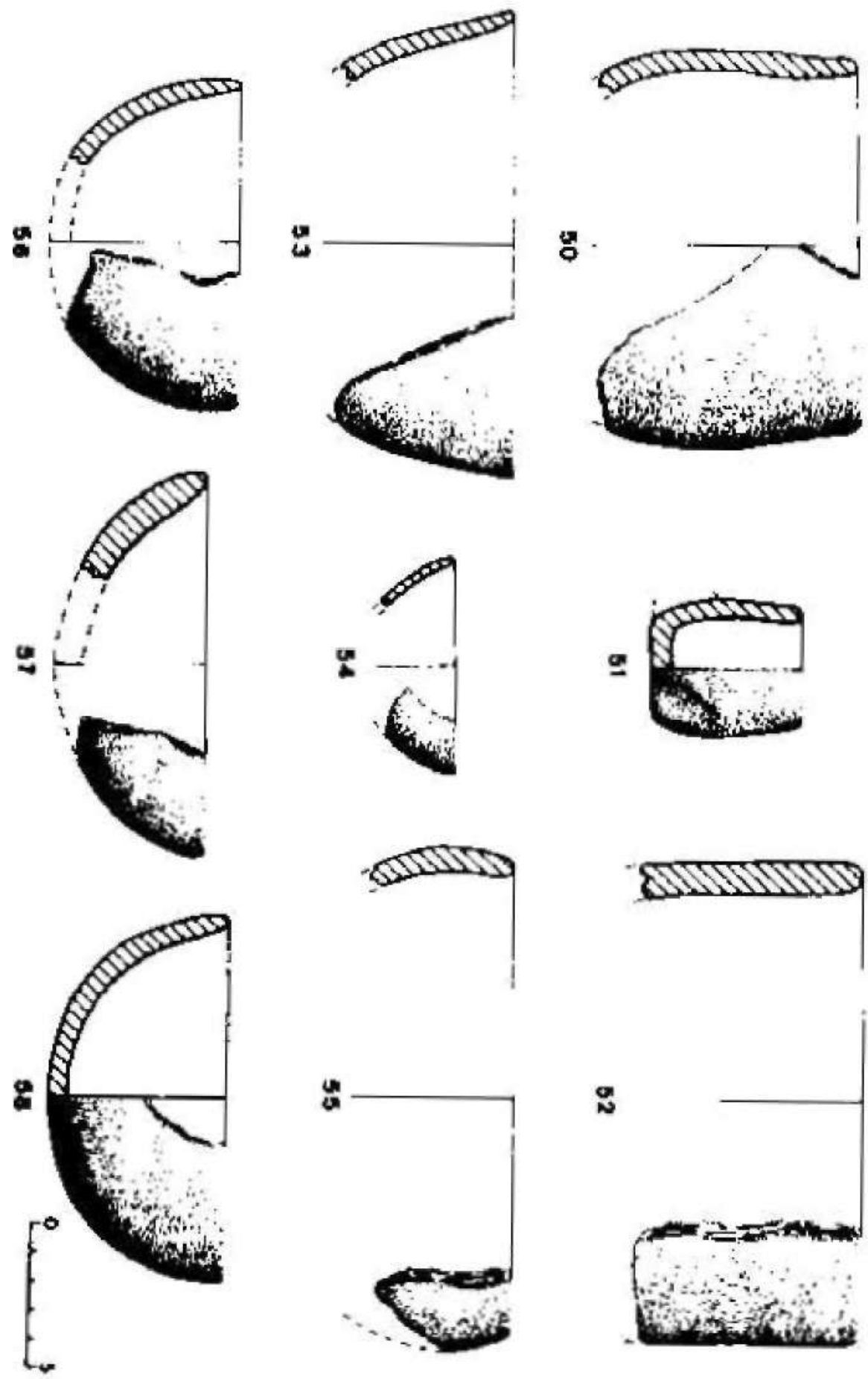

Fig. 9 

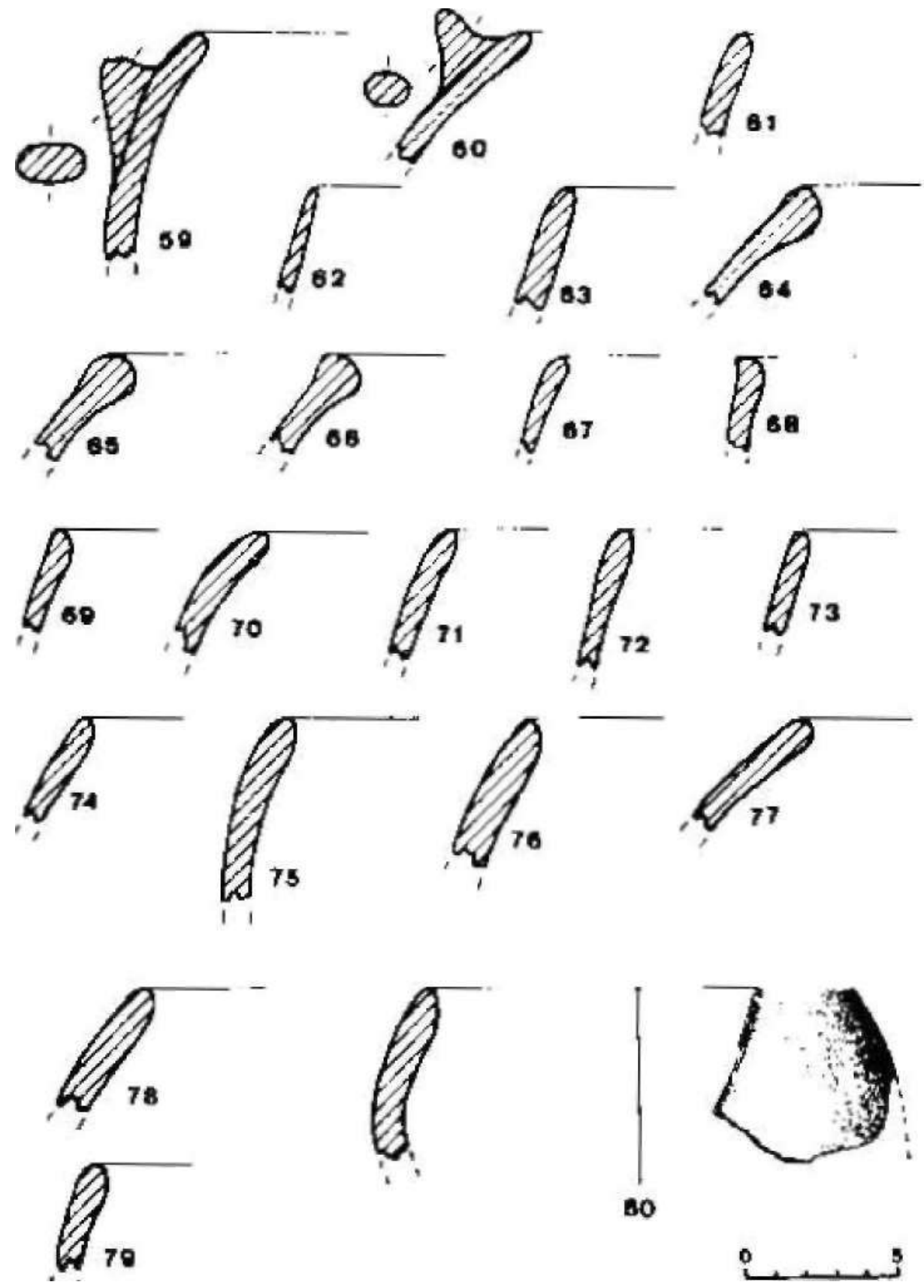

Fìg. 10 

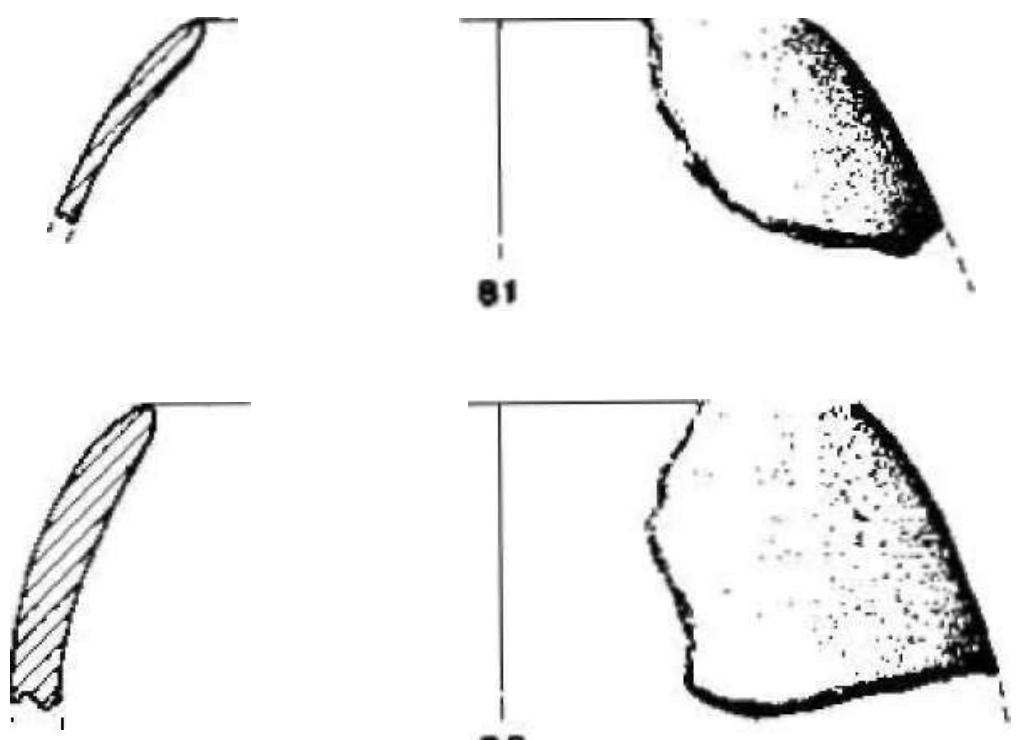

82
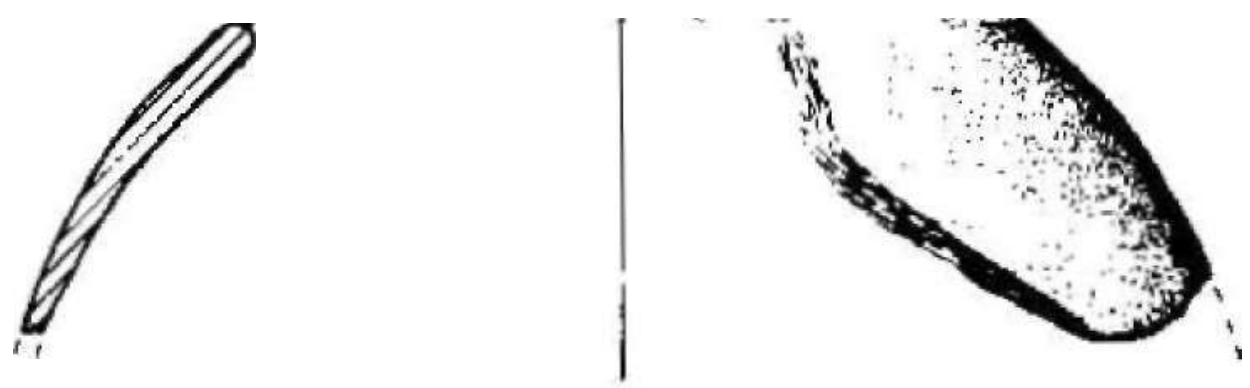

83

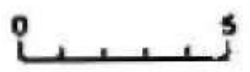

\section{Fie. 11}



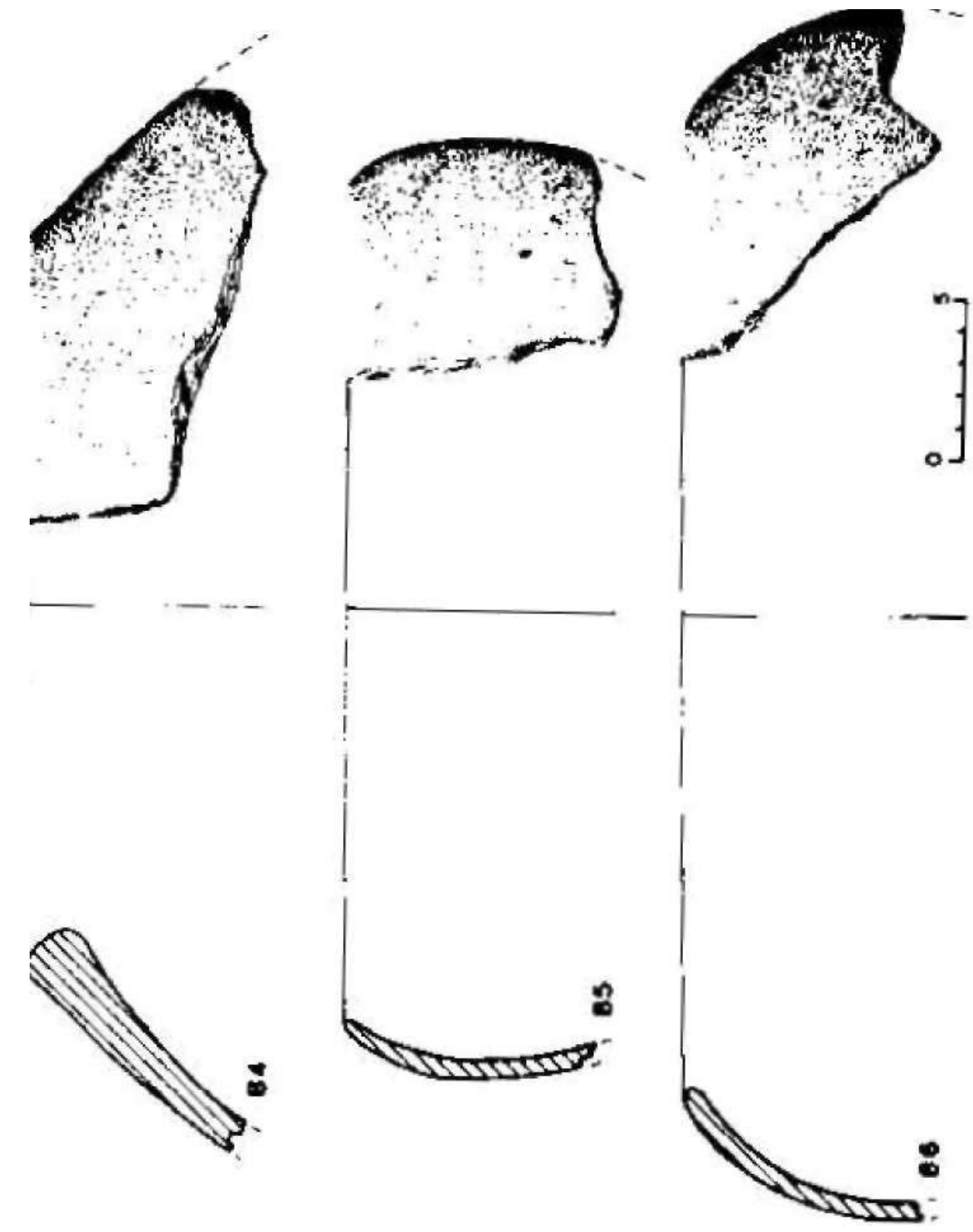

Fiz. 12 

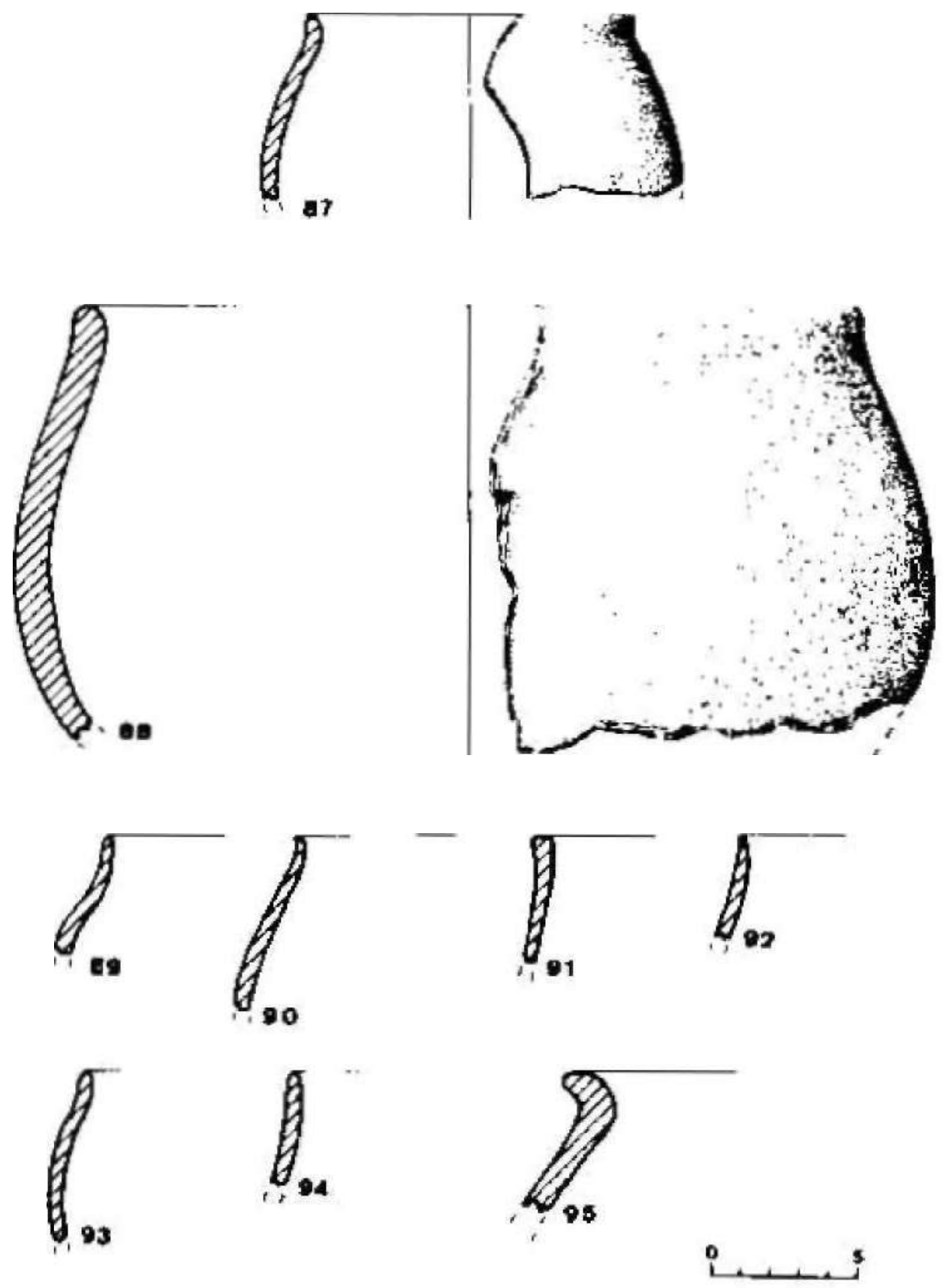

Fig. 13 


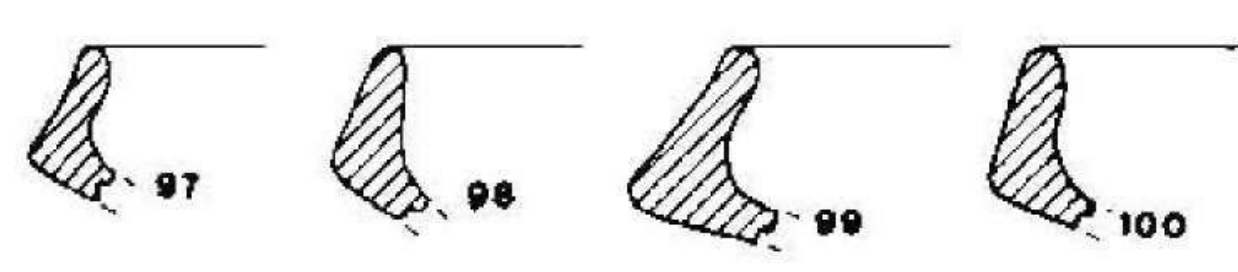

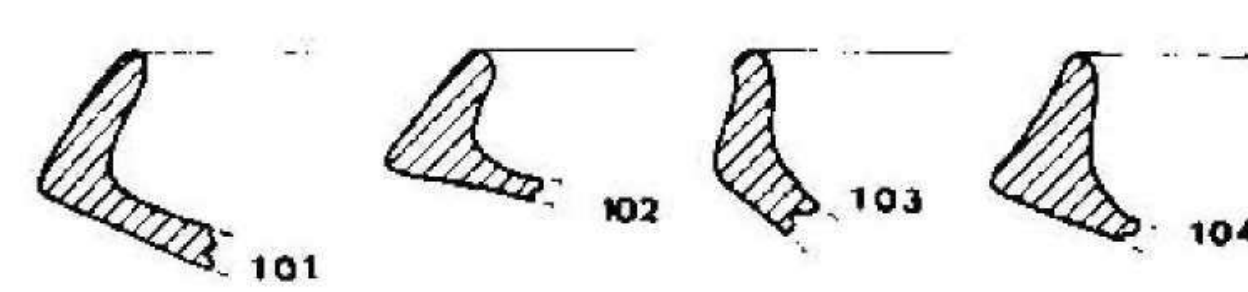

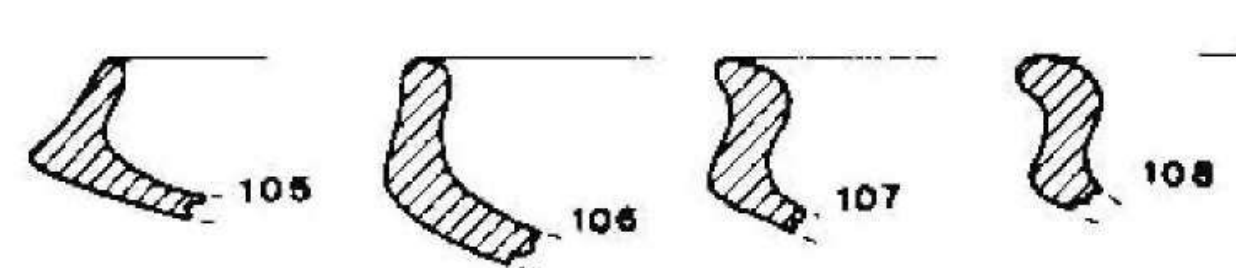

$$
\begin{aligned}
& \text { 家吅 } \\
& 8
\end{aligned}
$$




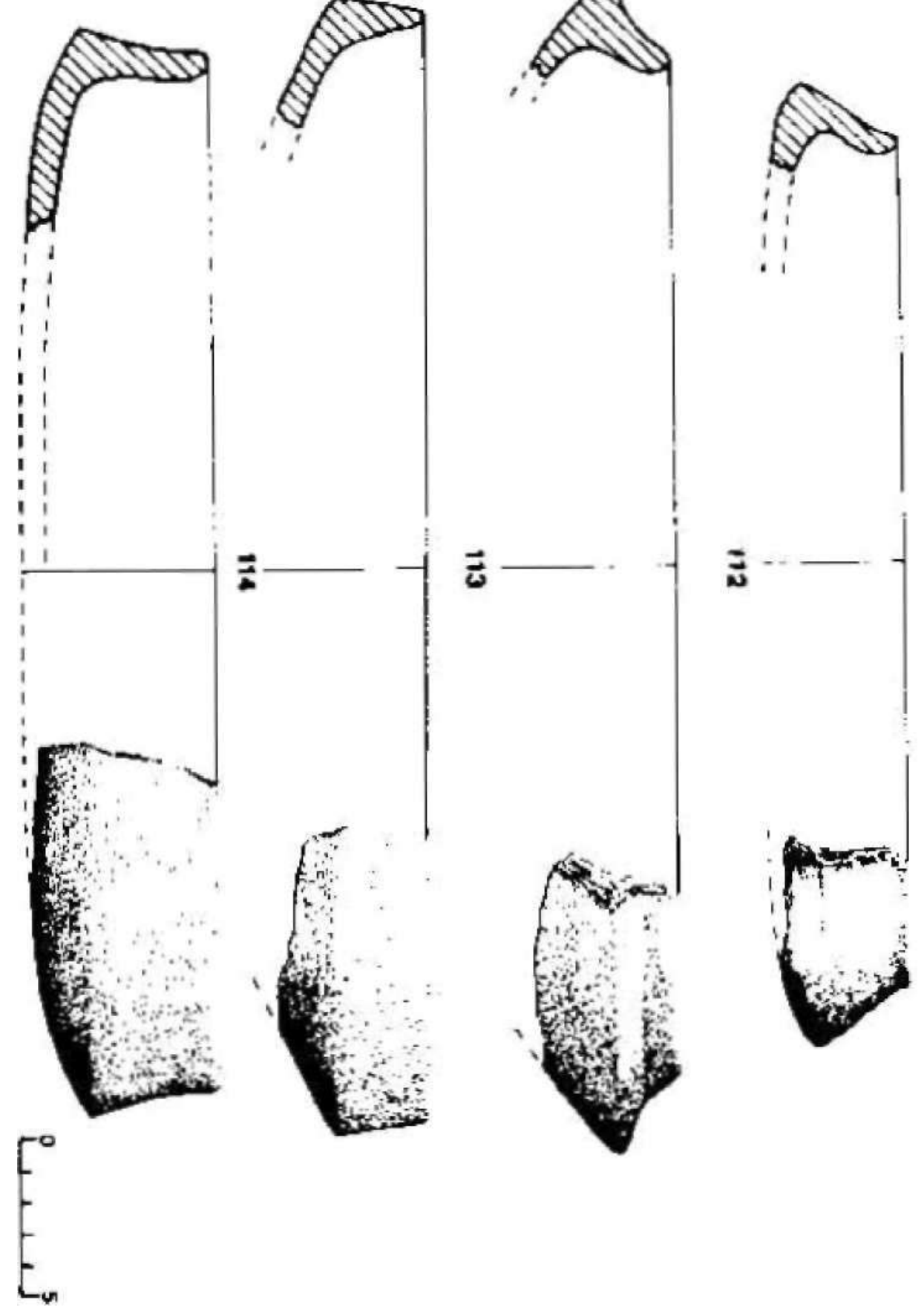

Fig. Is

86

--- Grupo de investigación P.A.I. HUM 236 | http://www.arqueocordoba.com/publ/anales.htm --- 


$$
a_{i=1}
$$



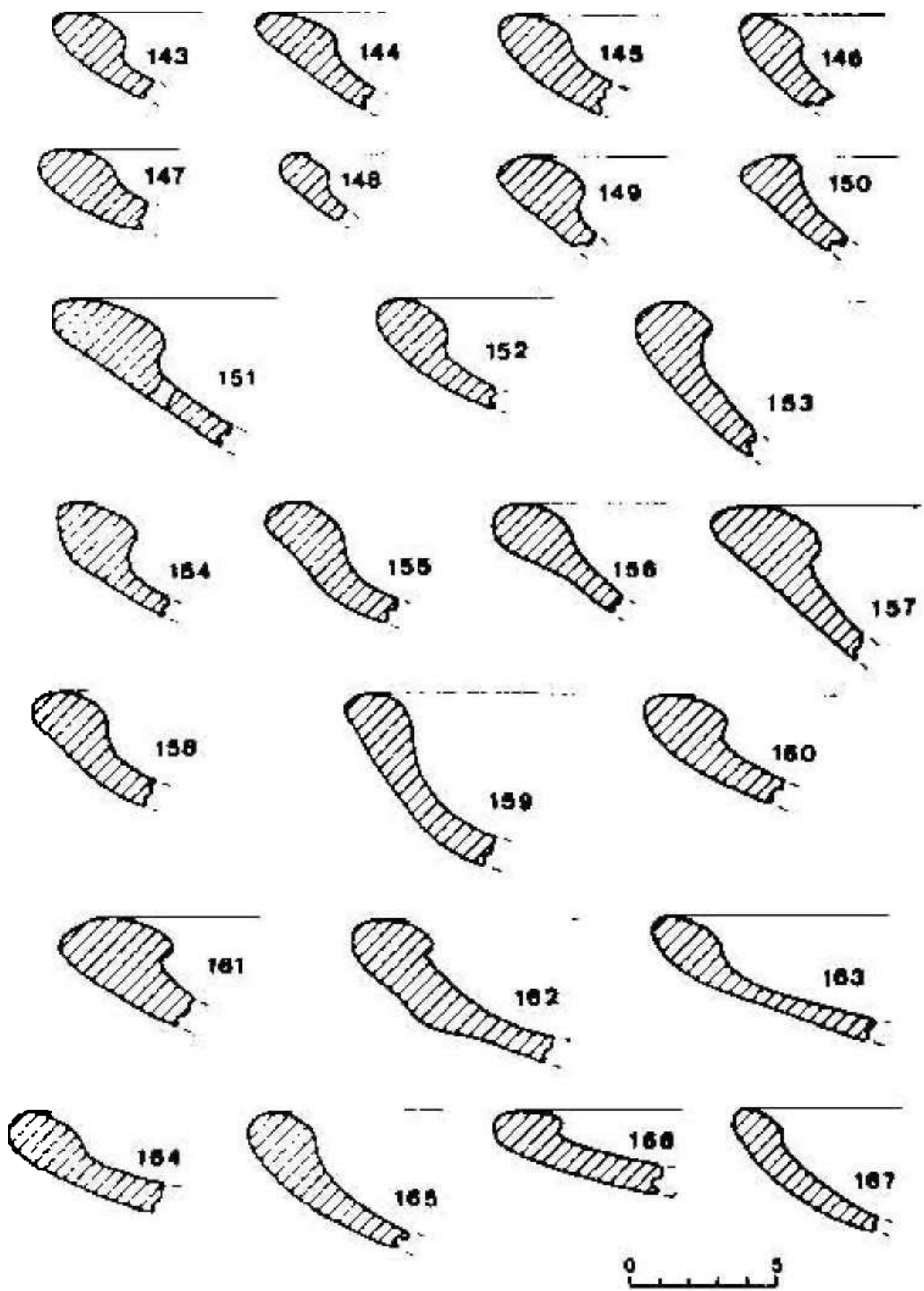

Fire. 17 

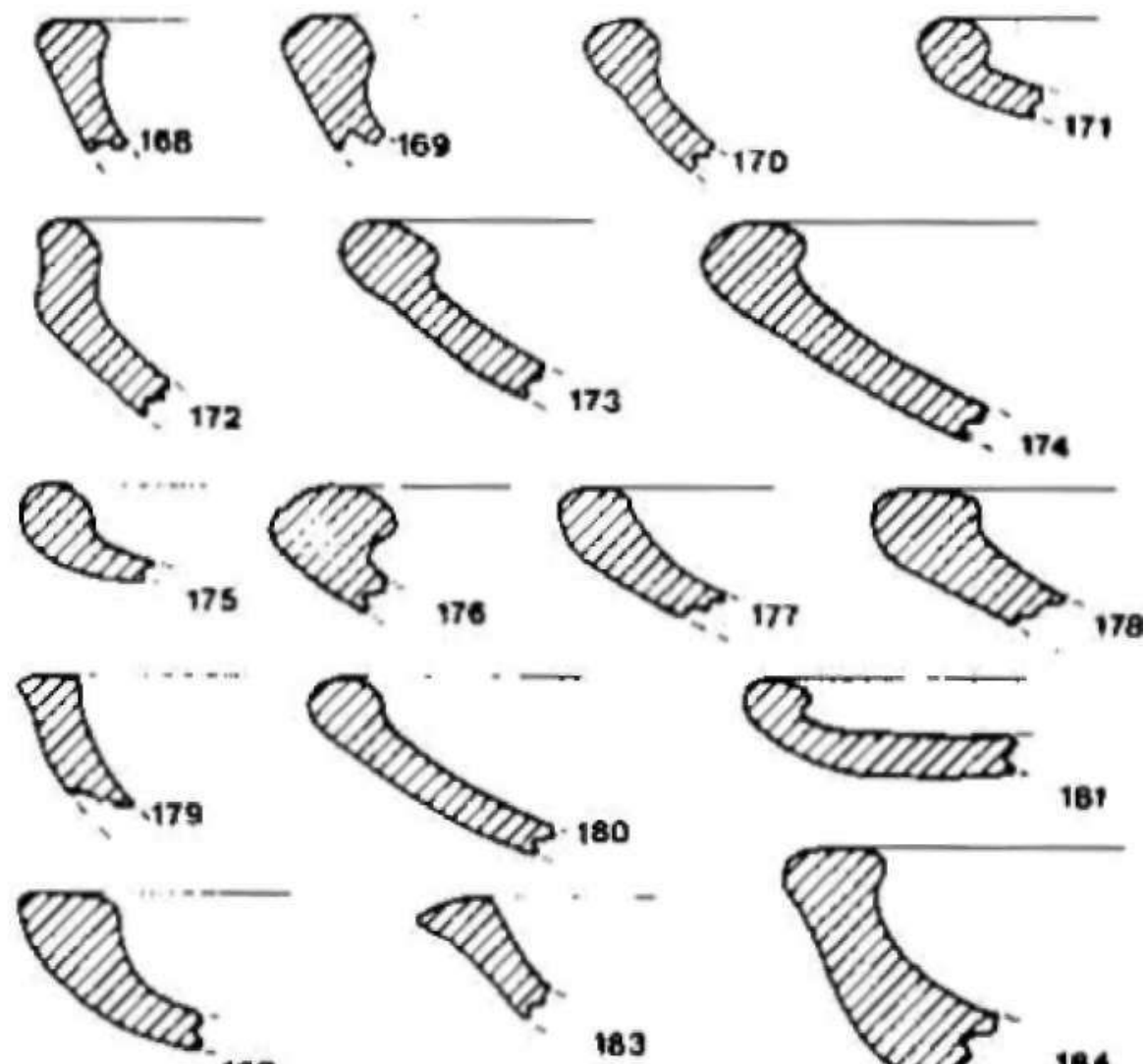

182

183
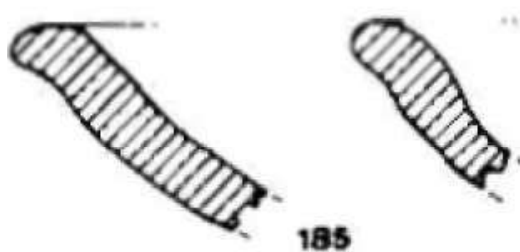

106

187

180

185
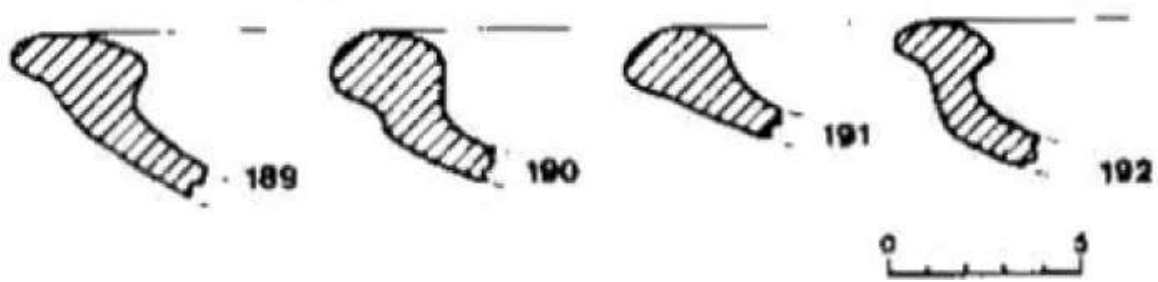

II. I8

--- Grupo de investigación P.A.I. HUM 236 | http://www.arqueocordoba.com/publ/anales.htm -.-XY 

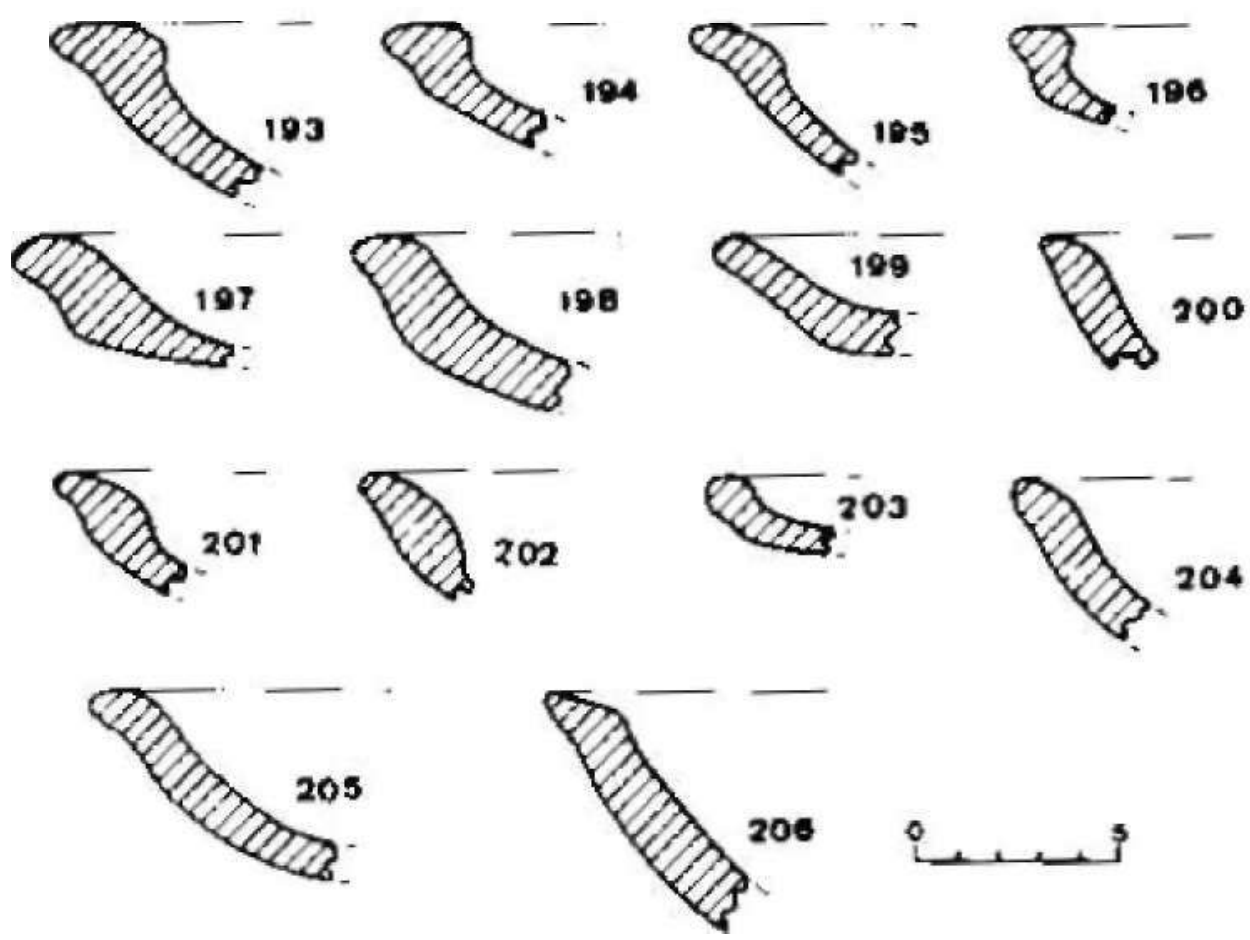

Fie. 19 

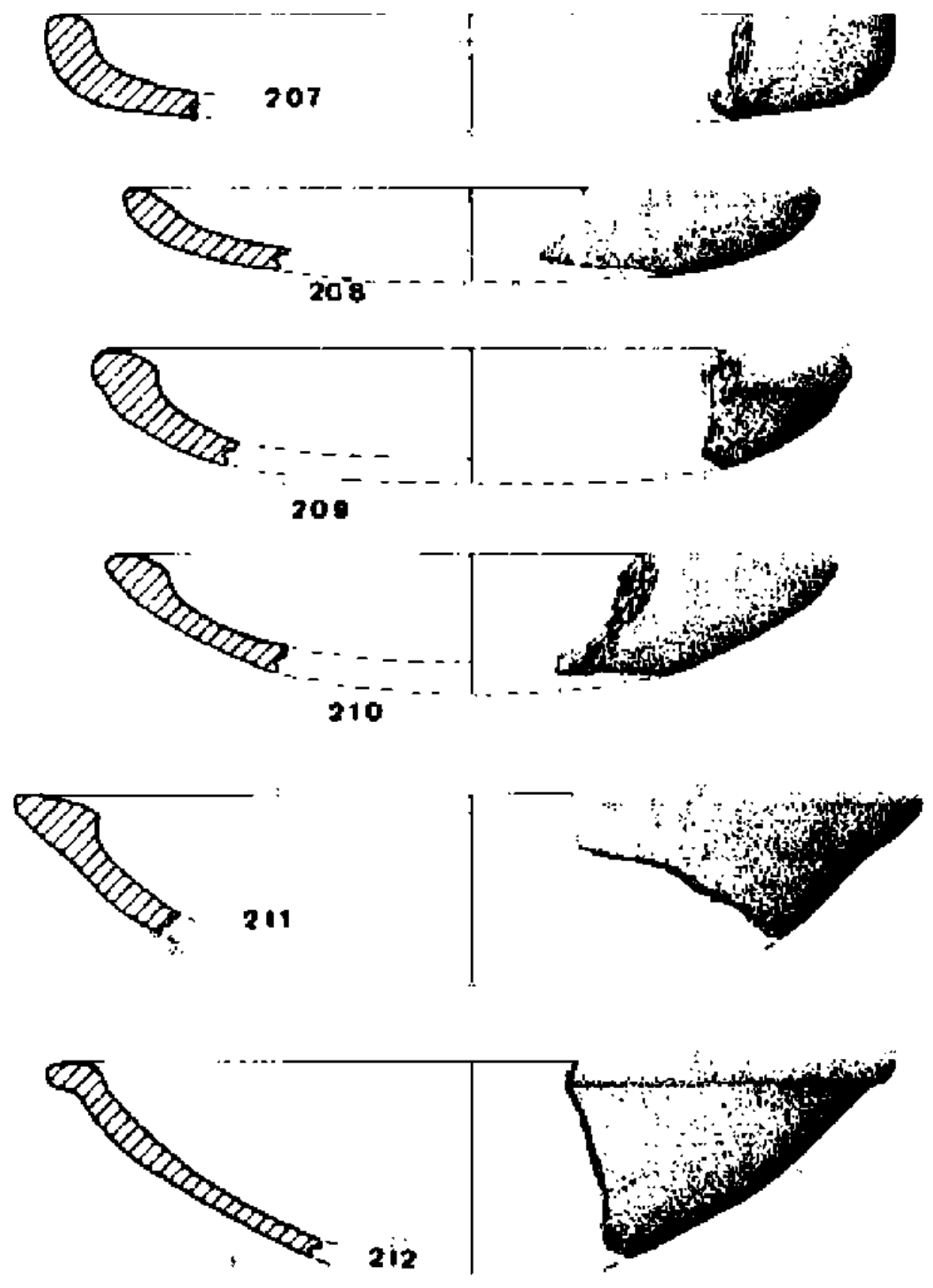

9

Fits. 20 


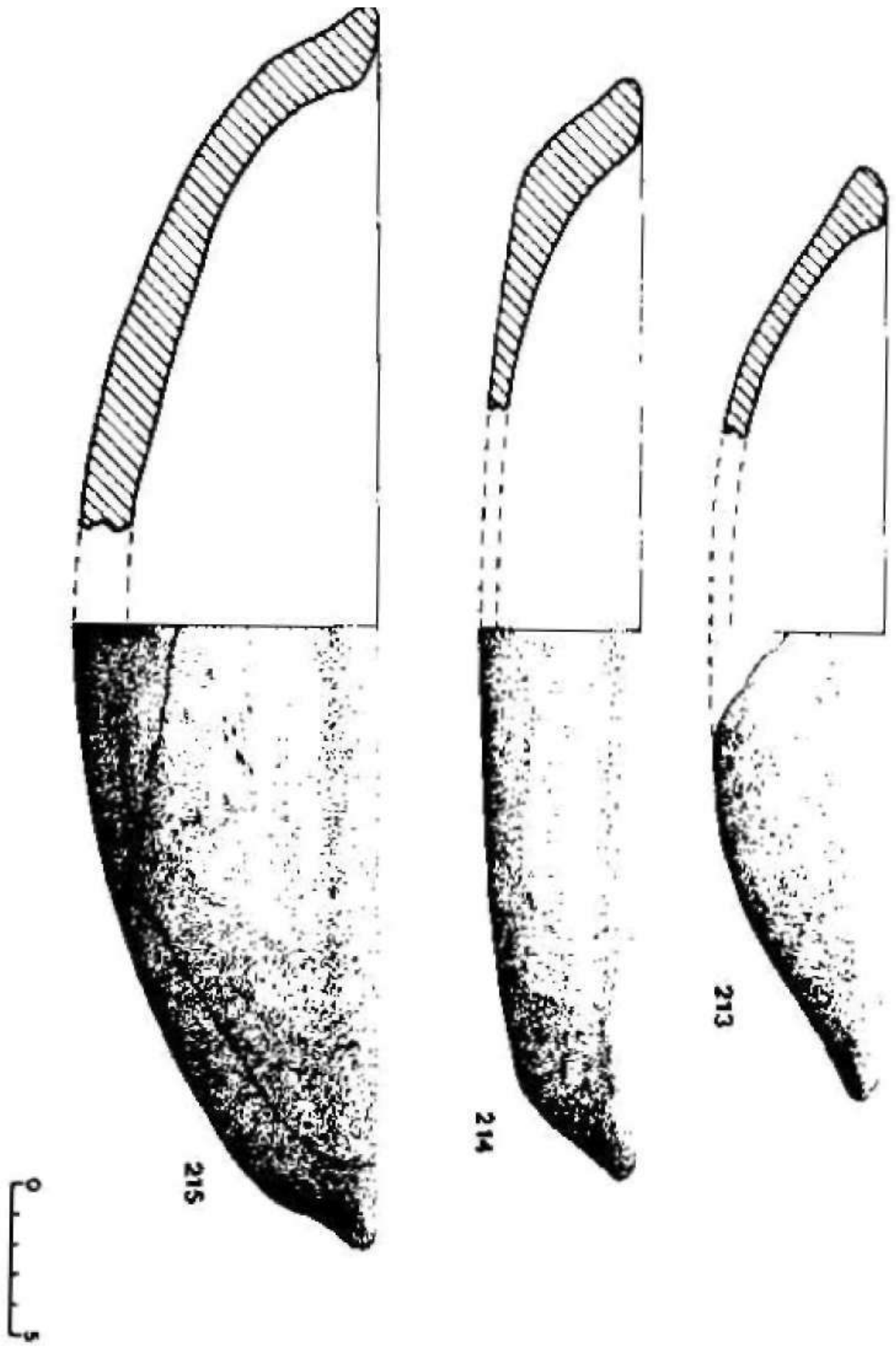

Fig. 21 

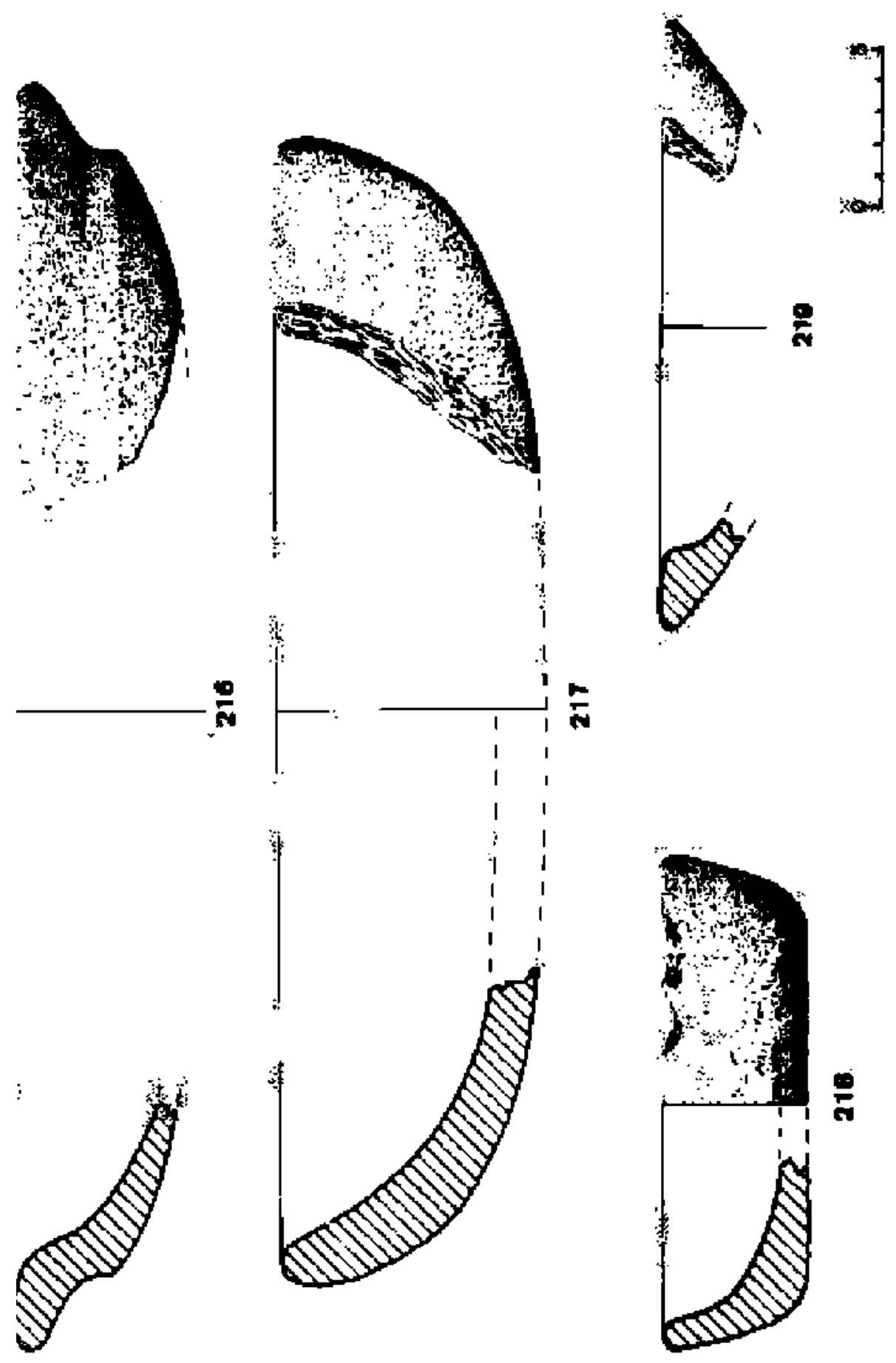

Fig. 22 

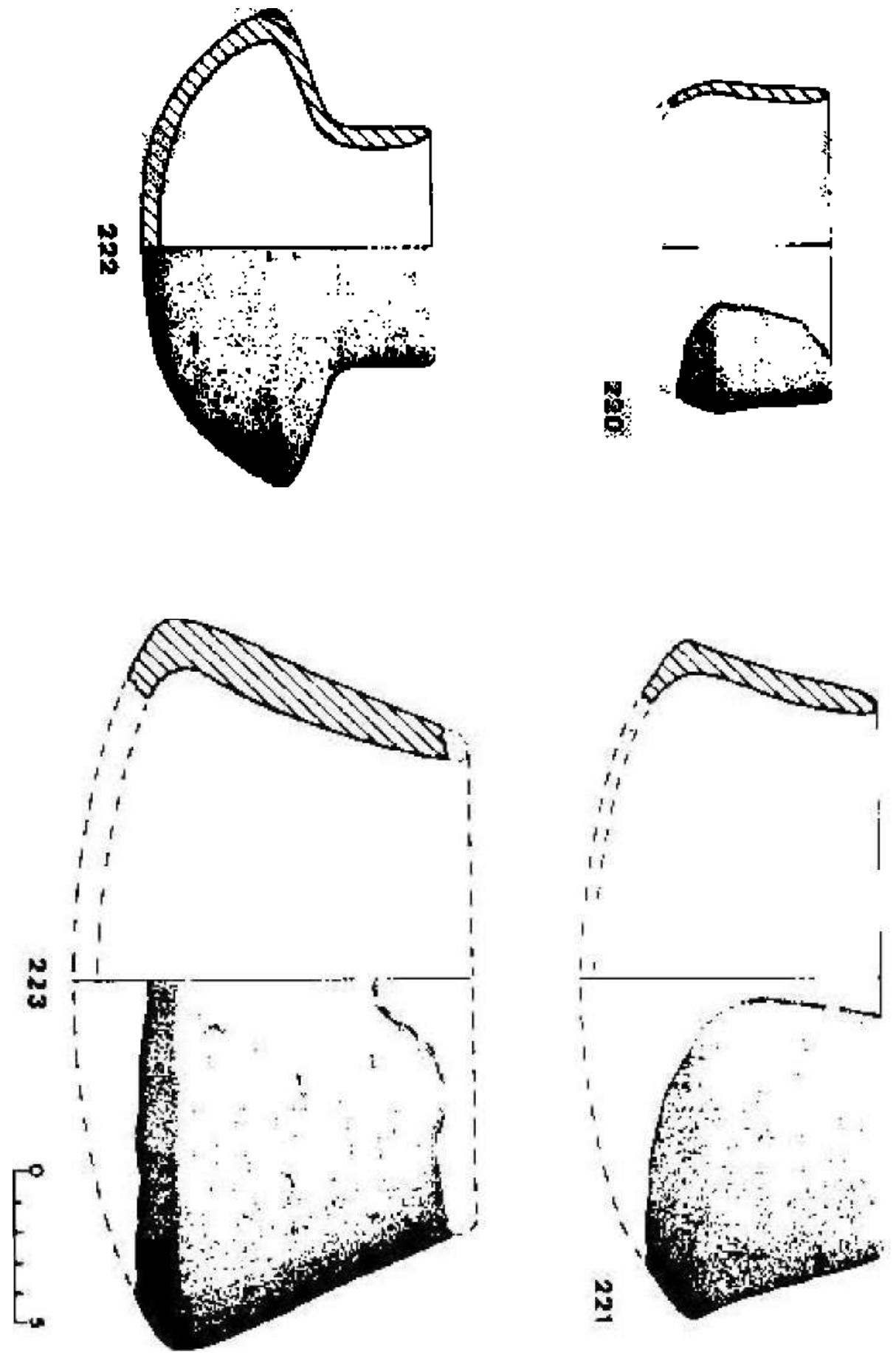

Fit. 23

94 --- Grupo de investigación P.A.I. HUM 236 | http://www.arqueocordoba.com/publ/anales.htm --- 

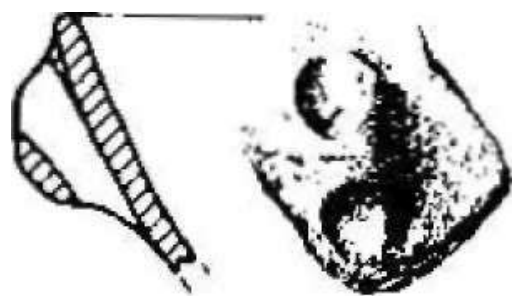

30
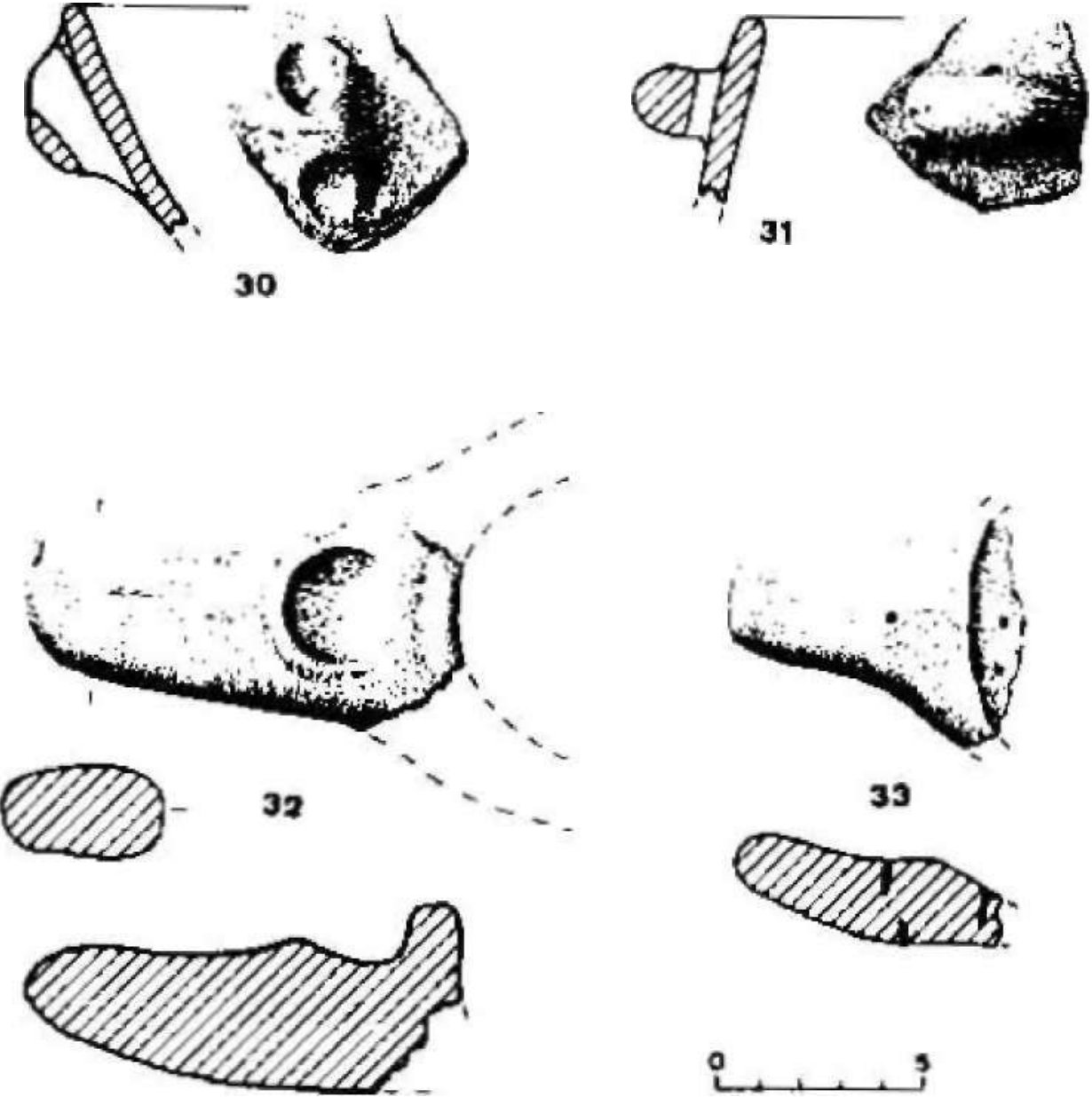

Fig. 24 

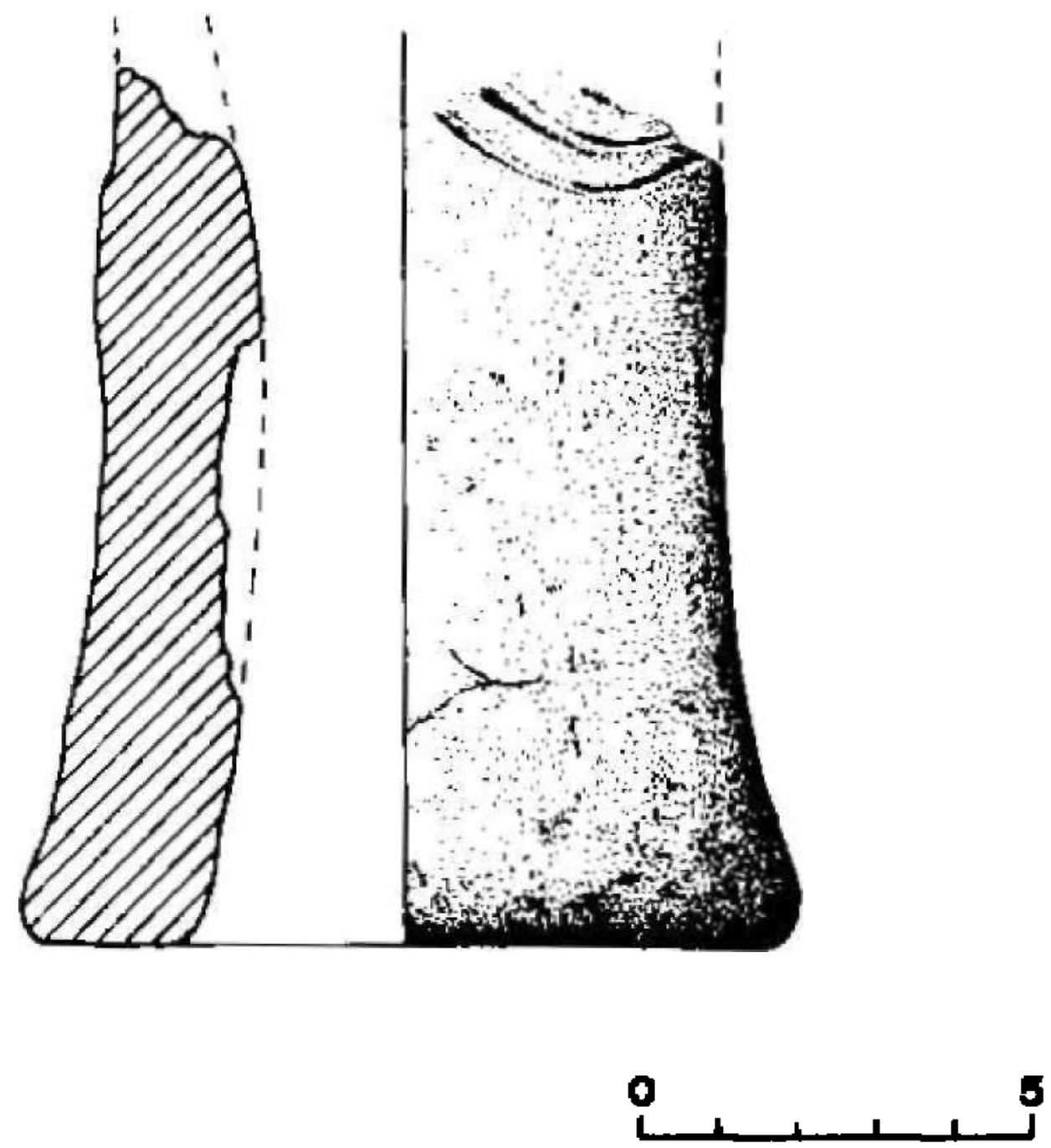

Fie. 25 $\overline{90}$ Grupo de investigación P.A.I. HUM 236 | http://www.arqueocordoba.com/publ/anales.htm --- 

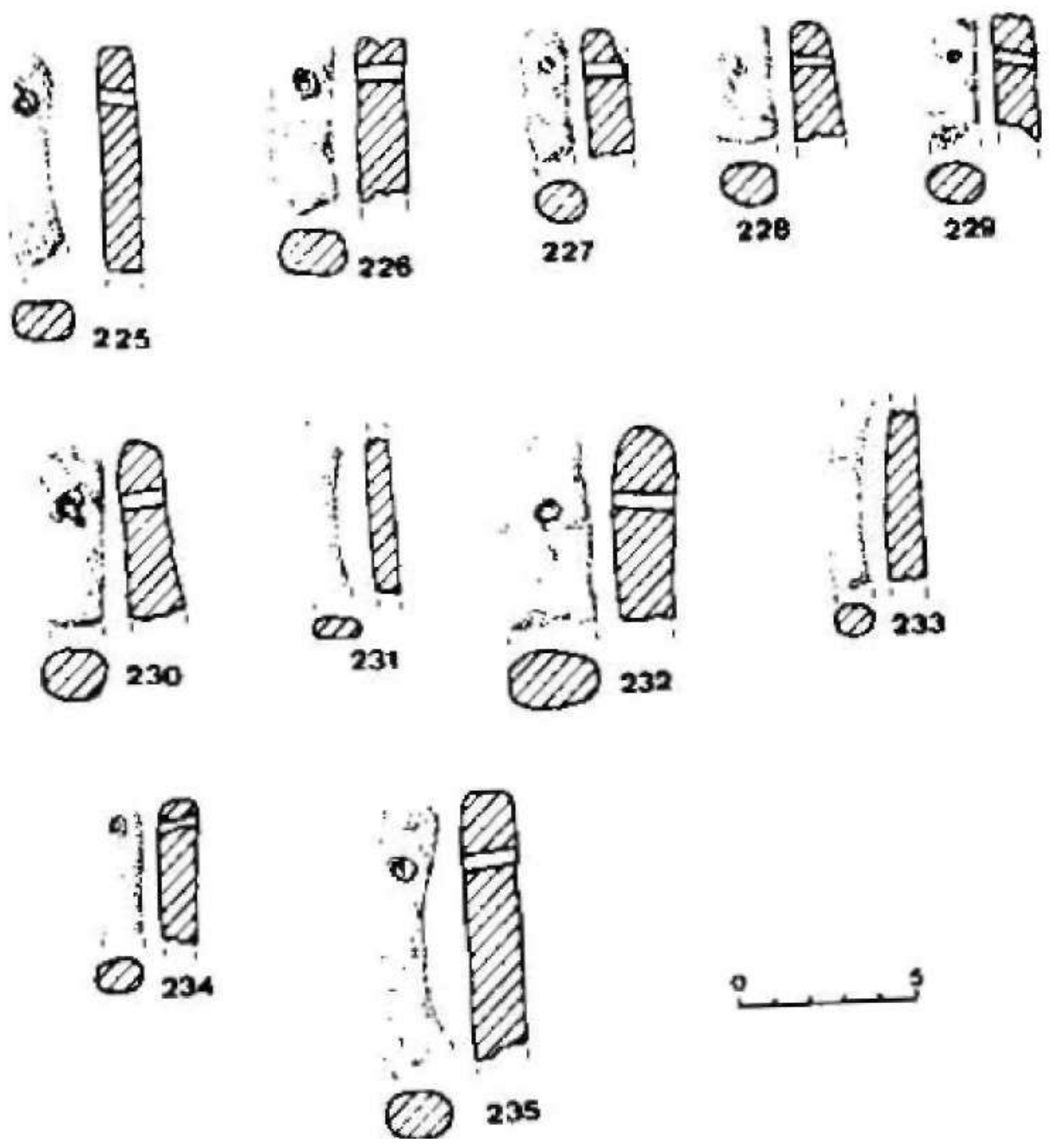

Fig. 26 

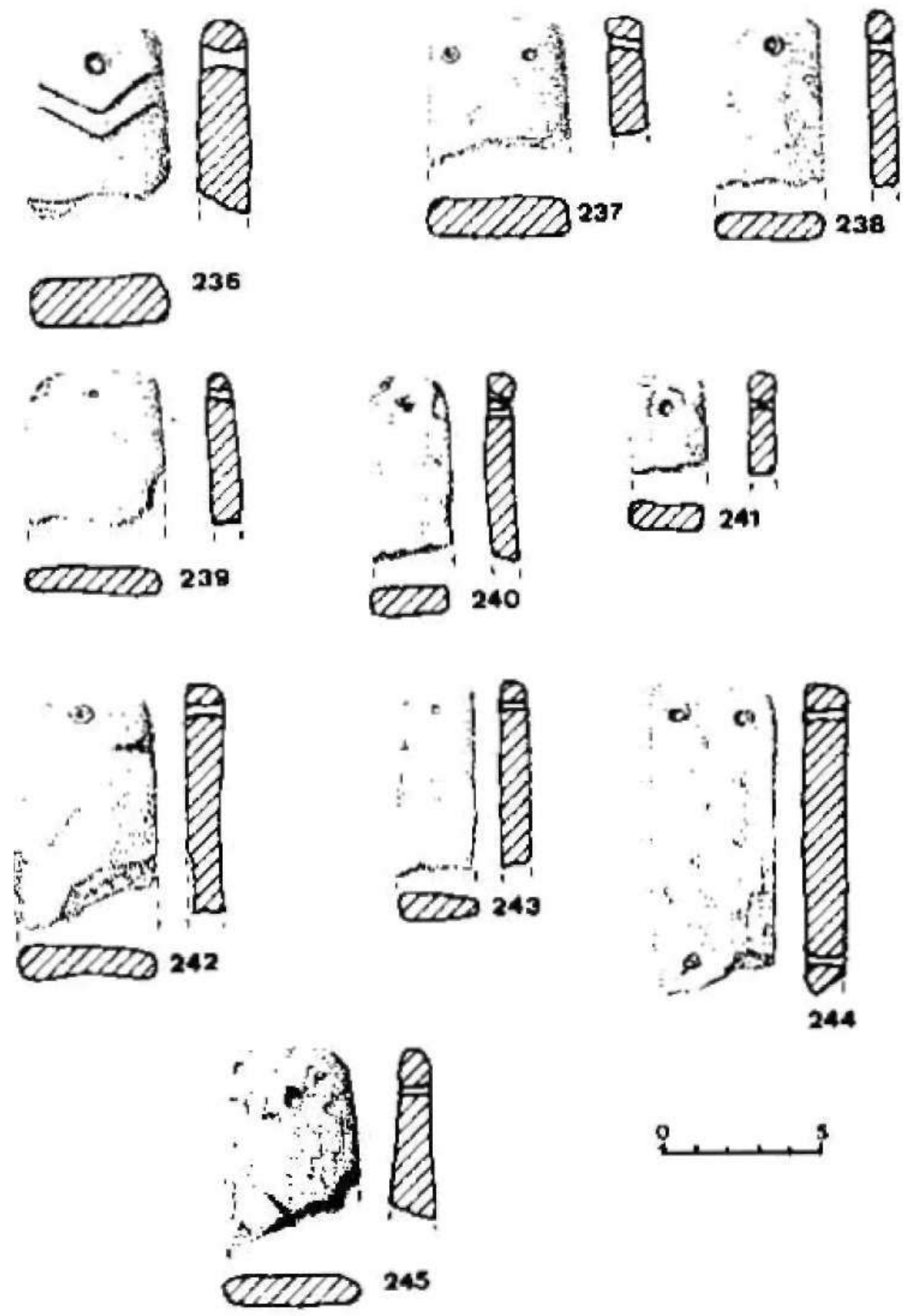

Fig. 27

\$M--- Grupo de investigación P.A.I. HUM 236 | http://www.arqueocordoba.com/publ/anales.htm --- 